Prepared in cooperation with the U.S. Fish and Wildlife Service

\title{
An Evaluation of the Toxicity of Potassium Chloride, Active Compound in the Molluscicide Potash, on Salmonid Fish and Their Forage Base
}

Open-File Report 2018-1080 



\section{An Evaluation of the Toxicity of Potassium Chloride, Active Compound in the Molluscicide Potash, on Salmonid Fish and Their Forage Base}

By Christine L. Densmore, Luke R. Iwanowicz, Anne P. Henderson, Vicki S. Blazer, Baileigh M. Reed-Grimmett, and Lakyn R. Sanders

Prepared in cooperation with the U.S. Fish and Wildlife Service

Open-File Report 2018-1080 


\title{
U.S. Department of the Interior \\ RYAN K. ZINKE, Secretary
}

\author{
U.S. Geological Survey \\ James F. Reilly II, Director
}

U.S. Geological Survey, Reston, Virginia: 2018

For more information on the USGS - the Federal source for science about the Earth, its natural and living resources, natural hazards, and the environment—visit https://www.usgs.gov or call 1-888-ASK-USGS.

For an overview of USGS information products, including maps, imagery, and publications, visit https://store.usgs.gov.

Any use of trade, firm, or product names is for descriptive purposes only and does not imply endorsement by the U.S. Government.

Although this information product, for the most part, is in the public domain, it also may contain copyrighted materials as noted in the text. Permission to reproduce copyrighted items must be secured from the copyright owner.

Suggested citation:

Densmore, C.L., Iwanowicz, L.R., Henderson, A.P., Blazer, V.S., Reed-Grimmett, B.M., and Sanders, L.R., 2018,

An evaluation of the toxicity of potassium chloride, active compound in the molluscicide potash, on salmonid fish and their forage base: U.S. Geological Survey Open-File Report 2018-1080, 33 p., https://doi.org/10.3133/ofr20181080. 


\section{Acknowledgments}

The authors wish to gratefully acknowledge many individuals for their contributions to this project. The authors thank Thomas Kielbasinski and Jim Daley of the New York State Department of Environmental Conservation for providing the Chinook Salmon and Joshua Kretzer of the U.S. Department of Agriculture-National Center for Cool and Cold Water Aquaculture for providing the brook trout for this study. USGS conducted the study through the Science Support Partnership with the U.S. Fish and Wildlife Service (USFWS), and Robyn Draheim and Paul Heimowitz of USFWS both facilitated its development. Linda Beck, Johnna Roy, and Jeffrey Herod of USFWS are also thanked for their assistance. Dr. Christine Moffitt of USGS provided valuable advice and technical expertise in the laboratory examination of the effects of aqueous potassium chloride on dreissenid mussels. Leetown Science Center (USGS) interns Emily Nadenbousch and Layne Leake as well as laboratory technicians Kathryn Spring, Darlene Bowling, and Pamela Whittington provided the technical support for this project. 


\section{Contents}

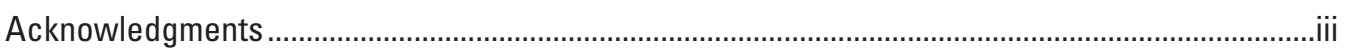

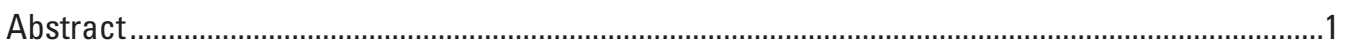

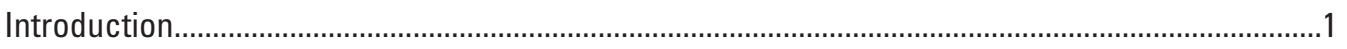

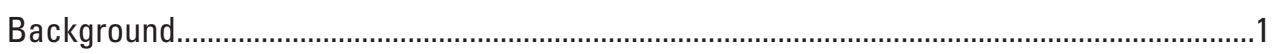

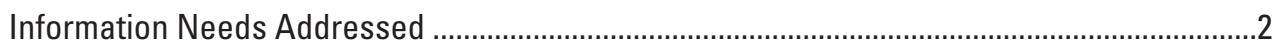

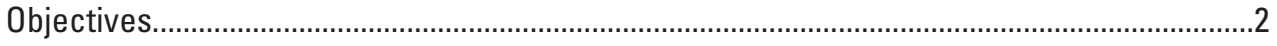

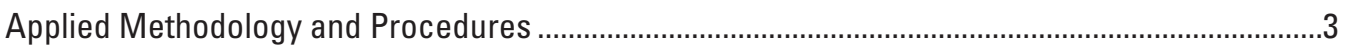

Acute Toxicity of Potassium Chloride to Juvenile Salmonid Fish ................................................3

Sublethal Physiological Impacts of Potassium Chloride to Juvenile Brook Trout—Acute Exposure

Sublethal Physiological Impacts of Potassium Chloride to Juvenile Chinook Salmon-

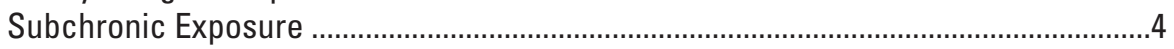

Acute Toxicity of Potassium Chloride to Invertebrate Forage of Salmonid Fish ........................

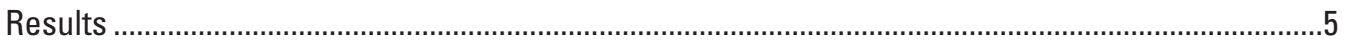

Water Quality and Water Chemistry ................................................................................

Acute Toxicity of Potassium Chloride to Juvenile Salmonid Fish .............................................5

Sublethal Physiological Impacts of Potassium Chloride to Juvenile Brook Trout —Acute

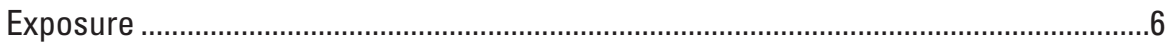

Sublethal Physiological Impacts of Potassium Chloride to Juvenile Chinook Salmon-

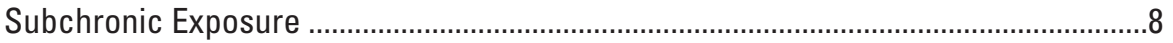

Acute Toxicity of Potassium Chloride to Invertebrate Forage of Salmonid Fish ........................9

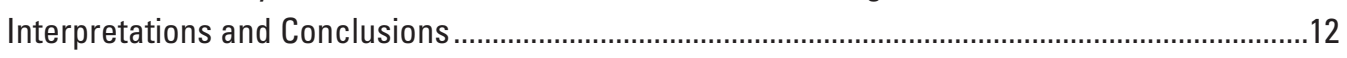

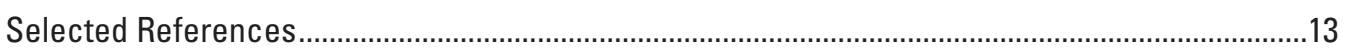

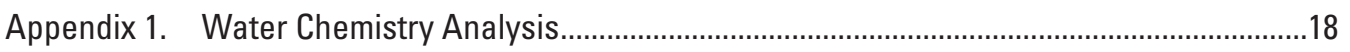

Appendix 2. Ionized potassium measurements-96-hour acute toxicity tests ...........................19

Appendix $3 A$. Water-quality measurements collected daily from all experimental tanks for the 96 -hour potassium chloride toxicity test, with brook trout at high baseline water

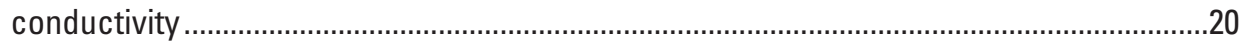

Appendix $3 B$. Water-quality measurements collected daily from all experimental tanks for the 96-hour potassium chloride toxicity test with brook trout at low baseline water conductivity.

Appendix $3 C$. Water-quality measurements collected daily from all experimental tanks for the 96-hour potassium chloride toxicity test with Chinook salmon at high baseline water

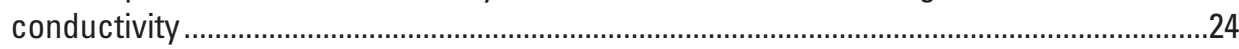

Appendix 3D. Water-quality measurements collected daily from all experimental tanks for the 96-hour potassium chloride toxicity test with Chinook salmon at low baseline water conductivity

Appendix $3 E$. Water-quality parameters for a 24-hour potassium chloride exposure evaluating physiological impacts on brook trout at high baseline water conductivity.

Appendix $3 F$. Water-quality parameters for a 24-hour potassium chloride exposure evaluating physiological impacts on brook trout at low baseline water conductivity ...........................29

Appendix $3 G$. Water-quality parameters for a 10-day potassium chloride exposure for the evaluation of physiological impacts on Chinook salmon. 
Appendix 4. Behavioral and morphological changes observed among acute toxicity tests for Chinook salmon and brook trout.

Appendix 5. Histological changes noted among brook trout and Chinook salmon in the 96-hour acute toxicity testing

Appendix 6. Log probit analysis calculation of the potassium chloride lethal concentration concentrations for daphniid toxicity trials.

\section{Figures}

1. Graphs showing plasma cortisol values for brook trout and Chinook salmon exposed to 0 and 200 milligrams per liter of potassium chloride.

2. Graph showing mortality of chironomid larvae during toxicity testing with potassium chloride exposures of 0-3,200 milligrams per liter

3. Graph showing mortality of Daphnia magna during toxicity testing with potassium chloride exposures of $0-3,200$ milligrams per liter...........................................................10

4. Graph showing lethal concentration values for daphniid exposure to potassium chloride. 11

5. Graph showing acute exposure to potassium chloride in crayfish

\section{Tables}

1. Chloride cell abundance among test groups .................................................................

2. Plasma chemistry data for brook trout following 24-hour exposure to potassium chloride at 200 milligrams per liter.

3A. Plasma chemistry data for Chinook salmon over time for 0 milligrams per liter and 200 milligrams per liter potassium chloride exposure groups.

$3 B$. Plasma chemistry for Chinook salmon throughout the 10 -day potassium chloride exposure trial. 


\section{Conversion Factors}

U.S. customary units to International System of Units

\begin{tabular}{|c|c|c|}
\hline Multiply & By & To obtain \\
\hline \multicolumn{3}{|c|}{ Length } \\
\hline inch (in.) & 2.54 & centimeter $(\mathrm{cm})$ \\
\hline inch (in.) & 25.4 & millimeter (mm) \\
\hline foot $(\mathrm{ft})$ & 0.3048 & meter $(\mathrm{m})$ \\
\hline mile (mi) & 1.609 & kilometer (km) \\
\hline mile, nautical (nmi) & 1.852 & kilometer $(\mathrm{km})$ \\
\hline yard (yd) & 0.9144 & meter (m) \\
\hline \multicolumn{3}{|c|}{ Volume } \\
\hline $\begin{array}{l}\text { barrel (bbl; petroleum, } 1 \text { barrel=42 } \\
\text { gal) }\end{array}$ & 0.1590 & cubic meter $\left(\mathrm{m}^{3}\right)$ \\
\hline ounce, fluid (fl. oz) & 0.02957 & liter (L) \\
\hline pint (pt) & 0.4732 & liter (L) \\
\hline quart (qt) & 0.9464 & liter (L) \\
\hline gallon (gal) & 3.785 & liter (L) \\
\hline gallon (gal) & 0.003785 & cubic meter $\left(\mathrm{m}^{3}\right)$ \\
\hline gallon (gal) & 3.785 & cubic decimeter $\left(\mathrm{dm}^{3}\right)$ \\
\hline million gallons (Mgal) & 3,785 & cubic meter $\left(\mathrm{m}^{3}\right)$ \\
\hline cubic inch $\left(\mathrm{in}^{3}\right)$ & 16.39 & cubic centimeter $\left(\mathrm{cm}^{3}\right)$ \\
\hline cubic inch $\left(\mathrm{in}^{3}\right)$ & 0.01639 & cubic decimeter $\left(\mathrm{dm}^{3}\right)$ \\
\hline cubic inch $\left(\mathrm{in}^{3}\right)$ & 0.01639 & liter (L) \\
\hline cubic foot $\left(\mathrm{ft}^{3}\right)$ & 28.32 & cubic decimeter $\left(\mathrm{dm}^{3}\right)$ \\
\hline cubic foot $\left(\mathrm{ft}^{3}\right)$ & 0.02832 & cubic meter $\left(\mathrm{m}^{3}\right)$ \\
\hline cubic yard $\left(\mathrm{yd}^{3}\right)$ & 0.7646 & cubic meter $\left(\mathrm{m}^{3}\right)$ \\
\hline cubic mile $\left(\mathrm{mi}^{3}\right)$ & 4.168 & cubic kilometer $\left(\mathrm{km}^{3}\right)$ \\
\hline acre-foot (acre-ft) & 1,233 & cubic meter $\left(\mathrm{m}^{3}\right)$ \\
\hline acre-foot (acre-ft) & 0.001233 & cubic hectometer $\left(\mathrm{hm}^{3}\right)$ \\
\hline \multicolumn{3}{|c|}{ Mass } \\
\hline ounce, avoirdupois (oz) & 28.35 & gram $(g)$ \\
\hline pound, avoirdupois (lb) & 0.4536 & kilogram (kg) \\
\hline ton, short $(2,000 \mathrm{lb})$ & 0.9072 & metric ton $(\mathrm{t})$ \\
\hline ton, long $(2,240 \mathrm{lb})$ & 1.016 & metric ton $(\mathrm{t})$ \\
\hline
\end{tabular}

Temperature in degrees Celsius $\left({ }^{\circ} \mathrm{C}\right)$ may be converted to degrees Fahrenheit $\left({ }^{\circ} \mathrm{F}\right)$ as follows:

$$
{ }^{\circ} \mathrm{F}=\left(1.8 \times{ }^{\circ} \mathrm{C}\right)+32 \text {. }
$$

Temperature in degrees Fahrenheit $\left({ }^{\circ} \mathrm{F}\right)$ may be converted to degrees Celsius $\left({ }^{\circ} \mathrm{C}\right)$ as follows:

$$
{ }^{\circ} \mathrm{C}=\left({ }^{\circ} \mathrm{F}-32\right) / 1.8 .
$$




\section{Abbreviations}

\begin{tabular}{|c|c|}
\hline ANOVA & analysis of variance \\
\hline ATP & adenosine triphosphate \\
\hline $\mathrm{Cl}^{-}$ & chloride ion \\
\hline${ }^{\circ} \mathrm{C}$ & temperature in degrees Celsius \\
\hline d & $\operatorname{day}(s)$ \\
\hline DOD & U.S. Department of Defense \\
\hline EPA & U.S. Environmental Protection Agency \\
\hline g & gram \\
\hline $\mathrm{g} / \mathrm{dL}$ & grams per deciliter \\
\hline h & hour(s) \\
\hline $\mathrm{Hb}$ & hemoglobin \\
\hline $\mathrm{HCO}_{3}^{-}$ & bicarbonate anion \\
\hline Hct & hematocrit \\
\hline IACUC & Institutional Animal Care and Use Committee \\
\hline $\mathrm{iCa}$ & ionized calcium \\
\hline $\mathrm{K}^{+}$ & ionized potassium \\
\hline $\mathrm{KCl}$ & potassium chloride \\
\hline $\mathrm{L}$ & liter \\
\hline $\mathrm{LC}_{50}$ & lethal concentration (50 percent) \\
\hline LSC & Leetown Science Center \\
\hline M & molar \\
\hline $\mathrm{mg}$ & milligram \\
\hline $\mathrm{mg} / \mathrm{dL}$ & milligrams per deciliter \\
\hline $\mathrm{mg} / \mathrm{L}$ & milligrams per liter \\
\hline $\mathrm{mL}$ & milliliter \\
\hline $\mathrm{mm}$ & millimeter \\
\hline $\mathrm{mmol} / \mathrm{L}$ & millimoles per liter \\
\hline $\mathrm{m} 0 \mathrm{sm} / \mathrm{L}$ & milliosmoles per liter \\
\hline $\mathrm{n}=$ & number of \\
\hline $\mathrm{Na}^{+}$ & ionized sodium \\
\hline $\mathrm{ng} / \mathrm{mL}$ & nanograms per milliliter \\
\hline NOEC & no observed effect concentration \\
\hline NYDEC & New York Department of Environmental Conservation \\
\hline PCV & packed (blood) cell volume \\
\hline
\end{tabular}




$\begin{array}{ll}\text { ppm } & \text { parts per million } \\ \text { PVC } & \text { polyvinyl chloride (synthetic polymer piping) } \\ \sec & \text { second(s) } \\ \mathrm{TCO}_{2} & \text { total carbon dioxide } \\ \mu \mathrm{L} & \text { microliter } \\ \mu \mathrm{S} / \mathrm{cm} & \text { microsiemens per centimeter (electrical conductivity measurement) } \\ \text { USDA-NCCCWA } & \text { U.S. Department of Agriculture, National Center for Cool and Cold } \\ & \quad \text { Water Aquaculture } \\ \text { USFWS } & \text { U.S. Fish and Wildlife Service } \\ \text { USGS } & \text { U.S. Geological Survey }\end{array}$




\title{
An Evaluation of the Toxicity of Potassium Chloride, Active Compound in the Molluscicide Potash, on Salmonid Fishes and Their Forage Base
}

\author{
By Christine L. Densmore, Luke R. Iwanowicz, Anne P. Henderson, Vicki S. Blazer, Baileigh M. Reed-Grimmett, \\ and Lakyn R. Sanders
}

\section{Abstract}

Potash, with the active ingredient potassium chloride $(\mathrm{KCl})$ is a chemical that is currently being evaluated for potential use as a molluscicide to combat invasive zebra mussels and quagga mussels in Western United States waters. Although data available for other freshwater fishes indicate that recommended treatment levels of potash as a molluscicide are sublethal, this has not been demonstrated for all salmonid species. The objectives of this study were to perform toxicity testing to determine the lethality of potassium chloride against selected species of salmonid fish (brook trout and Chinook salmon) and selected invertebrate forage, and to identify any potential adverse physiological impacts of $\mathrm{KCl}$ to these salmonids in water at treatment levels used for mollusk eradication. Minimal mortality ( $\mathrm{n}=1$ fish) was observed during 96-hour toxicity testing at $\mathrm{KCl}$ concentrations of 0 to 800 milligrams per liter $(\mathrm{mg} / \mathrm{L})$, indicating that the lethal concentration $\left(\mathrm{LC}_{50}\right)$ values in these salmonid species were considerably higher than realistic molluscicide treatment concentrations. Sublethal effects were examined through evaluation of behavioral and morphological (histological) observation as well as specific blood chemistry parameters (electrolytes, osmolality, glucose, and cortisol). There was no strong evidence of significant physiological impairment among the two salmonid species due to $\mathrm{KCl}$ exposure. Whereas statistically significant differences in some parameters were observed in association with $\mathrm{KCl}$ treatments, it is unlikely that these differences indicate adverse biological impacts. Acute toxicity tests were conducted with invertebrate species at $\mathrm{KCl}$ exposure concentrations of $0-3,200 \mathrm{mg} / \mathrm{L}$. Daphniid exposure trials resulted in differences in mortality among the test groups with higher mortality evident among the higher $\mathrm{KCl}$ exposure concentrations with a calculated $\mathrm{LC}_{50}$ value of $196 \mathrm{mg} / \mathrm{L} \mathrm{KCl}$ for a 48-hour exposure. Crayfish exposed to higher concentrations of $\mathrm{KCl}$ at or above $800 \mathrm{mg} / \mathrm{L}$ as specimens exhibited death or reversible paralysis. Chironomid larvae exposures were largely inconclusive because of cannibalistic behavior among the various test groups.

\section{Introduction}

\section{Background}

As a leading authority in the interagency Aquatic Nuisance Species Task Force, the U.S. Fish and Wildlife Service (USFWS) is responsible for the successful development and implementation of control measures for invasive aquatic mussels in United States waters. The U.S. Geological Survey (USGS), in keeping with its mission, provides science in support of the USFWS management goals. Invasive species of mussels that currently represent widespread threats in native aquatic habitats throughout the Nation include two species of Dreissena mussels, the zebra mussel (D. polymorpha) and the quagga mussel (D. rostriformis bugensis). Development of new methods and technologies that successfully kill or neutralize invasive mussels while doing no harm to native wildlife or ecosystems are an important part of a management strategy for these nuisance species.

Potash, with the active ingredient potassium chloride $(\mathrm{KCl})$, is a chemical that is currently being evaluated for potential use as a molluscicide to combat invasive zebra mussels and quagga mussels in Western United States waters. Potassium-based compounds have been evaluated experimentally for their efficacy in killing zebra mussels, particularly targeting the veliger larval stage (Fisher and others, 1991). Research results indicated that the potassium salts used, including $\mathrm{KCl}$, demonstrated killing capability against this invasive mussel species. During the winter of 2006, $\mathrm{KCl}$ was used at a concentration of approximately 100 milligrams per liter $(\mathrm{mg} / \mathrm{L})$ (or parts per million, $\mathrm{ppm})$ to successfully eradicate zebra mussels from a 12-acre abandoned rock quarry in Virginia without harming other aquatic fauna (Virginia Department of Game and Inland Fisheries, 2005). Whereas $\mathrm{KCl}$ is not an U.S. Environmental Protection Agency (EPA) approved pesticide and requires special permitting for use, it is generally considered a reasonably safe alternative to other molluscicides because of its low potential to impact 
non-target species (Virginia Department of Game and Inland Fisheries, 2005). The potential mechanism of action selectively impacting Dreissena mussels is thought to target the branchial epithelium interfering with $\mathrm{Na}^{+} / \mathrm{K}^{+} /$ATPase activity and impacting functional gas exchange (Fisher and others, 1991). Although no impacts on aquatic wildlife or human health at a target concentration for zebra mussel eradication of $100 \mathrm{mg} / \mathrm{L}$, have been reported there is not an extensive body of literature available to describe the potential chronic impacts of $\mathrm{KCl}$ on aquatic wildlife, nor have the impacts on all potential non-target aquatic wildlife species of interest been described. Before using such a new control measure, an understanding of the full potential scope of its effects on native wildlife must be developed. This body of knowledge would be especially valuable when considering application in habitats that support species of concern. Listed species of Pacific salmonid fish represent an important example.

Research into the efficacy of potash as a control method for dreissenid mussels under different water chemistry conditions and habitat have demonstrated that water chemistry plays an important role relative to the impacts of $\mathrm{KCl}$ as a molluscicide (Moffitt and others, 2016). Specifically, low conductivity water with low levels of sodium supports the efficacy of $\mathrm{KCl}$ treatment. High conductivity and total dissolved solids (TDS) in water reduce the effectiveness of $\mathrm{KCl}$ as a biocide for dreissenid mussels (C. Moffitt, USGS, oral commun., 2016). It is likely that the same mechanisms and principles of action of $\mathrm{KCl}$ (based on dysfunction of the branchial $\mathrm{Na}^{+} / \mathrm{K}^{+} /$ATPase activity) may be anticipated for other aquatic invertebrates and fish. Therefore, water chemistry conditions that provide low conductivity and low dissolved solids, particularly sodium, are probably best suited to demonstrate the potential toxicityrelated impacts on these species of interest.

Although the use of liquid KCl-based potash may be a viable control mechanism against invasive Dreissena mussels in the Pacific Northwest region, consideration must first be given to the potential scope of effects on the endangered populations of salmonid fish that may cohabitate these waters. Acute toxicity testing for potash and other chemical mixtures with $\mathrm{KCl}$ as the active ingredient have been reported for some species (Vijayavel and Balasubramanian, 2007), but very little data specific to salmonid fish are available. Whereas extrapolation of data available for other freshwater fish indicates that these treatment levels of potash as a molluscicide are sublethal, this has not been demonstrated for all salmonid species. In addition, data that describe the potential subclinical physiological effects of this chemical on these species are not widely available.

\section{Information Needs Addressed}

Control of aquatic invasive species is an important component of the mission of the USFWS. Likewise, protection of listed species such as endangered northwest salmonid populations is central to the mission of the USFWS. Both of these issues are addressed by this study. The acute and chronic toxicity testing of $\mathrm{KCl}$ provides valuable information related to the potential scope and side effects of KCL-based potash as a molluscicide to control invasive Dreissena mussels in sensitive habitat. The effects were assessed using relevant salmonid fish species and invertebrate forage species as surrogates for the endangered salmonid populations and their prey items that would likely cohabitate waters of the Pacific Northwest where molluscicide treatment may be used. Thus, the acute (lethal) toxic effects of this compound on species of concern and their forage base were analyzed. In addition, the study determined whether potentially chronic, sublethal effects may exist with additional consequences for overall health status and survival of these salmonid fish populations. The scope of work has broad applicability for use of potassium-based compounds as molluscicides in waters inhabited by salmonid fish.

Preventing the establishment of aquatic invasive species in general, and dreissenid mussels in particular, is a high conservation priority for USFWS Region 1, the Pacific Region including Hawaii, Idaho, Oregon, Washington State, and the Pacific Islands . The establishment of dreissenid mussel populations in the Columbia River Basin in the Pacific Northwest could have real and significant consequences on efforts to protect listed species, but the ecological effects of invasive mussel establishment go beyond listed species to the overall health of aquatic communities as well. For instance, ssenid mussel infestations have been implicated in shifts in invertebrate and fish communities, an increased frequency of toxic algal blooms, and the spread of avian botulism (Getchell and Bowser, 2006; Nalepa, 2010). Alternatively, any rapid response to a mussel introduction must be predicated on minimizing harm to our trust resources. The investigation into the potential negative effects of potash on salmonids provides managers of Pacific Northwest waters and elsewhere better information on the most appropriate and effective tools for eradicating dreissenid mussels before they become established.

Although it is not possible to accurately predict when and where an invasion will take place, it is known that the range of dreissenid mussels is encroaching upon the Pacific Northwest. As a result, there is an increased risk of mussel introduction and establishment. The more information available to support the development of best management practices before a mussel introduction occurs, the greater the likelihood that rapid response efforts will be successful. This initial investigation into the toxicity of potash to salmonids and their prey items addresses critical matters of potential ecological impact to inform responsible application of $\mathrm{KCl}$-based molluscicides in the Columbia River Basin.

\section{Objectives}

1. To perform acute toxicity tests to evaluate the lethality of potash $(\mathrm{KCl}$, proposed for use as a molluscicide in Pacific Northwest salmonid habitat) against representative species of salmonid fish (brook trout and Chinook salmon) and their forage base. 
2. To perform toxicity tests to identify any potential physiological impacts of $\mathrm{KCl}$ in water at relevant treatment levels on selected species of salmonid fish.

\section{Applied Methodology and Procedures}

\section{Acute Toxicity of Potassium Chloride to Juvenile Salmonid Fish}

Toxicity testing was performed with two species of salmonid fish, one each from the genera Oncorhynchus and Salvelinus, which were representative of salmonid fish populations of concern in the Pacific Northwest region. Juvenile Chinook salmon (Oncorhynchus tshawytscha) and juvenile brook trout (Salvelinus fontinalis) were utilized for this study (Densmore and others, 2018). Brook trout were used as a proxy species for the Endangered Species Act listed bull trout (Salvelinus confluentus; U.S. Fish and Wildlife Service 1999), as these fish are difficult to obtain in quantities sufficient for toxicity testing, and physiological reactivity to $\mathrm{KCl}$ is expected to be similar between the two species. The use of these fish in this study was performed in accordance with an Institutional Animal Care and Use Committee (IACUC) approved protocol (Leetown Science Center IACUC Protocol 2016-001). Approximately 1,500 Chinook salmon fry (about 2.5 grams [g]/fish) were obtained from New York Department of Environmental Conservation, Salmon River Fish Hatchery (Altmar, N.Y.). Approximately 1,000 brook trout fry (about $3 \mathrm{~g} /$ fish) were obtained from the U.S. Department of Agriculture, National Center for Cool and Cold Water Aquaculture (Kearneysville, W.Va.). After delivery, fish were maintained in 1,000-liter (L) holding stock tanks with flow-through spring water (at a temperature of 12.5 degrees Celsius, or ${ }^{\circ} \mathrm{C}$ ) supplied to Leetown Science Center (LSC) wet laboratories. Approximately 1 week prior to the onset of the experiments, the fish were transferred to closed recirculating holding tank systems for acclimation to experimental water maintained at $12-13{ }^{\circ} \mathrm{C}$. All fish were maintained using standard laboratory protocols for transport, care, and handling in accordance with both the LSC Fish Health Laboratory Standard Operating Procedures for the Acquisition, Care, and Handling of Laboratory Animals (Leetown Science Center, USGS, written commun., 2016) as well as the associated IACUC-approved protocol.

Toxicity experiments were performed with replicate treatment groups and unexposed control groups. Reagent grade $\mathrm{KCl}$ was utilized for testing, as $\mathrm{KCl}$ is the active ingredient in industrial potash at over 99.9 percent standard content, and the mechanism of action of potash on dreissenid mussels is ascribed to $\mathrm{KCl}$ toxicity (Fisher and others, 1991). Furthermore, there are variations in the formulation of industrial grade potash so that reagent grade $\mathrm{KCl}$ provides for better uniformity and consistency across experiments (United Nations Industrial Development Organization-International
Fertilizer Development Center, 1998). Experimental concentrations of $\mathrm{KCl}$ dilutions were monitored throughout experimental exposures with a portable meter measuring potassium anions in water (Horiba LAQUAtwin potassium $\mathrm{K}^{+}$compact ion meter, Horiba Scientific Ltd., Kyoto, Japan). Other waterquality parameters were measured as needed with standard portable submersible meters (Yellow Springs Instrument Co., Yellow Springs, Ohio) or water-quality test kits (Hach Chemical Company, Loveland, Ohio). Previous investigations to evaluate the impacts of $\mathrm{KCl}$ in water on dreissenid mussels have demonstrated that conductivity and TDS significantly impacted the efficacy of $\mathrm{KCl}$ as a molluscicide (C. Moffitt, USGS, oral commun., 2016). Because of this finding, two formulations of experimental water were used for each species of fish and acute toxicity tests were performed at both high and low water conductivity levels. Undiluted spring water that supplies the LSC wet laboratories was used for the high conductivity tests. Undiluted (flowing) spring water had a conductivity of approximately 680 microsiemens per centimeter $(\mu \mathrm{S} / \mathrm{cm})$, alkalinity $\left(\mathrm{HCO}_{3}^{-}\right)$of $120 \mathrm{mg} / \mathrm{L}, \mathrm{Na}^{+}$of $3.5 \mathrm{mg} / \mathrm{L}$, and $\mathrm{K}^{+}$of $1.8 \mathrm{mg} / \mathrm{L}$. A second test formulation was developed using spring water diluted with deionized laboratory water to low conductivity of approximately $150 \mu \mathrm{S} / \mathrm{cm}$; this low conductivity water was also used for both acute toxicity tests and acute sublethal effects testing with brook trout. Water samples including both high and low conductivity formulations, with and without the addition of $\mathrm{KCl}$ reagent at a calculated $800 \mathrm{mg} / \mathrm{L}$, were analyzed by a commercial water-quality laboratory (Reliance Laboratories Inc., Martinsburg, W.Va.) for the presence of total calcium $(\mathrm{Ca})$, total magnesium $(\mathrm{Mg})$, total potassium $(\mathrm{K})$, total sodium $(\mathrm{Na})$, and total chloride $(\mathrm{Cl})$.

Acute toxicity tests were conducted as static replacement 96-hour toxicity tests (U.S. Environmental Protection Agency, 1996b) to determine the lethality of $\mathrm{KCl}$ and ascertain any sublethal histological changes associated with $\mathrm{KCl}$ exposures. Experimental exposures were conducted in triplicate at concentrations of $0,25,50,100,200,400$, and $800 \mathrm{mg} / \mathrm{L} \mathrm{KCl}$. Circular tanks containing $18 \mathrm{~L}$ of water with supplemental aeration were used as the static testing vessels. These tanks were partially submerged in troughs with flowing spring water to maintain a consistent suitable temperature of approximately $13{ }^{\circ} \mathrm{C}$ in the testing tanks. Seven fish were present in each replicate tank ( $\mathrm{n}=21$ fish in total per treatment level; $\mathrm{n}=147$ fish in total per experimental trial). The toxicity testing was performed four times: high and low background water conductivity using either brook trout or Chinook salmon. For each test, a 100-percent water change with $\mathrm{KCl}$ replacement was performed 48 hours into the experimental period. Fish were monitored four times daily throughout the experiment for presence of moribund or dead fish. Daily observations related to both gross appearance and behavior were quantitatively recorded. At the conclusion of the 96-hour test period, all remaining fish were rapidly euthanized with a lethal dose of tricaine methanesulfonate $(500 \mathrm{mg} / \mathrm{L}$, loss of righting reflex in less than 30 seconds) applied to test water, followed by transection of the proximal spinal cord. Gross necropsy was 
performed for each specimen and any abnormalities were recorded. All fish from one replicate tank for each exposure group ( $\mathrm{n}=7$ fish) were preserved in Z-fix (buffered formalin based) tissue fixative for potential histological analysis. The seven specimens from the 0,100 , and $800 \mathrm{mg} / \mathrm{L}$ exposure groups were processed for histopathological analysis by light microscopy using standard methodology (Luna, 1992; Reimschuessel and others, 1992). For each species, seven additional fish were taken directly from the holding tank and euthanized/ handled as previously described for histological sampling to provide "non-experimental" control groups for histological reference. In addition to evaluation for the presence of lesions and abnormalities, chloride cell counts were performed for gill tissues. Chloride cells were counted in interlamellar spaces (five consecutive lamellae) for three randomly selected gill segments from each fish.

\section{Sublethal Physiological Impacts of Potassium Chloride to Juvenile Brook Trout-Acute Exposure}

Modified toxicity testing was similarly performed using brook trout to evaluate the potential sublethal physiological effects of $\mathrm{KCl}$ on fish health. Brook trout were held in triplicate (3 fish/tank) in 14 replicate tanks (aquaria with $36 \mathrm{~L}$ of water and supplemental aeration) for both control (no $\mathrm{KCl}$ added) and treatment $(200 \mathrm{mg} / \mathrm{L} \mathrm{KCl}$ added) groups. Static exposure tests were performed for 24 hours, and aquaria were maintained at $12-13{ }^{\circ} \mathrm{C}$, as previously described. Fish were observed for activity and behavior throughout the exposure period, also as previously described. At the end of 24 hours, fish were rapidly euthanized with a lethal dose of tricaine methanesufonate $(500 \mathrm{mg} / \mathrm{L}$, loss of righting reflex in less than30 seconds) applied to test water. Morphometric parameters (total length, total weight) were measured and blood was immediately collected by use of caudal venipuncture using 1-milliliter $(\mathrm{mL})$ syringes with 26-gauge needles and held on ice in 2-mL heparanized microcentrifuge tubes. Gross necropsy was performed for all specimens, and gill tissues were preserved in Z-Fix tissue fixative (Anatech Ltd., Battle Creek, Mich.) and archived for processing and evaluation. For one specimen from each replicate, whole blood was used for blood chemistry analysis with the iStat clinical chemistry analyzer and the CHEM8+cartridge (Abbott Point of Care, Inc., Princeton, N.J.). Plasma chemistry parameters evaluated included sodium, potassium, chloride, ionized calcium, total $\mathrm{CO}_{2}$, glucose, hematocrit, and hemoglobin. Plasma was collected from the remainder of the blood samples using centrifugation and frozen at $-80^{\circ} \mathrm{C}$ pending further analysis. Plasma samples were used to evaluate plasma osmolality with an Osmette ${ }^{\mathrm{TM}}$ osmometer (Precision Systems, Inc., Natick, Mass.) using 50-microliter $(\mu \mathrm{L})$ plasma samples in duplicate. Plasma cortisol was determined using a competitive enzymelinked immunoassay as described by Carey and McCormick (1998), with modifications. Adaptations of this assay included the sourcing of the cortisol-HRP-conjugate and rabbit anticortisol antibody from Fitzgerald Industries (Acton, Mass,). In addition, SureBlue Select (KPL Inc.; Seracare, Milford, Mass.) was used as the enzyme substrate for color development. Optical density was read using a SpectraMax M4 (Molecular Devices, Sunnyvale, Calif.) and plasma cortisol concentrations were determined by use of interpolation to a standard curve using SoftMaxPro v. 6.2.2 (Molecular Devices, Sunnyvale, Calif.). A four-parameter curve was used for sample interpolation. The range of the assay defined by the standard curve was $1-400$ nanograms per milliliter $(\mathrm{ng} / \mathrm{mL})$.

\section{Sublethal Physiological Impacts of Potassium Chloride to Juvenile Chinook Salmon- Subchronic Exposure}

A subchronic toxicity test using Chinook salmon was performed in a 190-gallon recirculating holding tank with chilled $\left(12{ }^{\circ} \mathrm{C}\right)$ water formulated to conductivity of approximately $300 \mu \mathrm{S} / \mathrm{cm}$. Two test trials were run consecutively for 10 days, with added $\mathrm{KCl}$ levels of $0 \mathrm{mg} / \mathrm{L}$ (control) and $200 \mathrm{mg} / \mathrm{L}$ (treatment). For each test trial, 60 fish were used. Twelve fish per group were removed from the study on days 1 and 6 , with the remainder on day 10 . Fish were rapidly euthanized with a lethal dose of tricaine methanesulfonate $(500 \mathrm{mg} / \mathrm{L}$, loss of righting reflex in less than 30 seconds). Subsequent tissue sampling and analyses were performed as described for sublethal impacts analysis with brook trout (gross and behavioral observations, plasma chemistry parameters, osmolality, and cortisol evaluations).

\section{Acute Toxicity of Potassium Chloride to Invertebrate Forage of Salmonid Fish}

Daphnia magna and chironomid midge larvae (bloodworms) were purchased from a commercial supplier (Sachs Systems Aquaculture, St. Augustine, Fla.). Acute toxicity tests (U.S. Environmental Protection Agency, 1996a) were performed with these specimens using two-fold serial dilutions of $\mathrm{KCl}(0-3,200 \mathrm{mg} / \mathrm{L})$ in LSC laboratory spring water diluted with deionized water to a baseline conductivity of $270 \mu \mathrm{S} / \mathrm{cm}$. Baseline water conductivity levels were derived based on a combination of acclimation trials with these species and previous observations of the effects of conductivity on $\mathrm{KCl}$ efficacy as a molluscicide (C. Moffit, USGS, oral commun., 2016). A 3-molar (M) solution of aqueous $\mathrm{KCl}$ (Sigma Aldrich Co., St. Louis, Mo.) was used to prepare the $\mathrm{KCl}$ test solutions. Upon receipt, invertebrates of each species were acclimated to the $270 \mu \mathrm{S} / \mathrm{cm}$ baseline test water at $15^{\circ} \mathrm{C}$ in the holding vessels over an approximate 24-hour period with 10 individual specimens per container. Acid-washed glass $150-\mathrm{mL}$ beakers containing $50 \mathrm{~mL}$ of test solution were used as test vessels in a $15^{\circ} \mathrm{C}$ incubator to maintain the temperature. Following the acclimation period, specimen viability was 
checked by motility and condition, and the proper amounts of aqueous $\mathrm{KCl}$ solution were added to each test container and mixed to achieve the target concentrations. Serial dilutions of $\mathrm{KCl}$ and a negative control exposure were run in triplicate at the following $\mathrm{KCl}$ concentrations: $0 \mathrm{mg} / \mathrm{L}$ (control), $25 \mathrm{mg} / \mathrm{L}$, $50 \mathrm{mg} / \mathrm{L}, 100 \mathrm{mg} / \mathrm{L}, 200 \mathrm{mg} / \mathrm{L}, 400 \mathrm{mg} / \mathrm{L}, 800 \mathrm{mg} / \mathrm{L}$,

$1,600 \mathrm{mg} / \mathrm{L}$, and $3,200 \mathrm{mg} / \mathrm{L}$. The acute toxicity test was conducted for 48 hours, and organism viability (motility and condition) were checked at 2, 4, and 24 hours. Mortality was assessed and recorded at each observation interval and at the 48-hour conclusion.

Additional 48-hour trials were conducted with crayfish (Procambarus sp., approximately 32 millimeters [mm] average length) purchased from the same commercial supplier. Crayfish were held at five $\mathrm{KCl}$ test concentrations (0, 200, 400,800 , and $1,600 \mathrm{mg} / \mathrm{L}$ ) in four replicate tanks (1 L total water volume) with small sections of 0.75 -inch-diameter polyvinyl chloride (PVC) tubing along the tank bottoms to offer cover. Baseline water conductivity of $270 \mu \mathrm{S} / \mathrm{cm}$ was used, similar to the water used in the other invertebrate toxicity trials, and water temperature was maintained at approximately $21^{\circ} \mathrm{C}$, and an airstone provided aeration for each tank. Each replicate tank contained three crayfish. Crayfish were monitored for apparent mortality at $0,9,24,32$, and 48 hours. At each observation interval, presumptively dead crayfish were identified based on lack of righting reflex and lack of response to tactile stimuli. These presumptively dead specimens were removed from the tanks and placed in individual freshwater containers $(0 \mathrm{mg} / \mathrm{L} \mathrm{KCl}$ with all other parameters as previously described) for 24 hours to verify mortality based on persistence of lack of response/righting reflex. Observations of cannibalism (loss of all or part of an individual specimen) within a replicate tank resulted in the removal of the replicate from the remainder of the study.

\section{Results}

\section{Water Quality and Water Chemistry}

Water chemistry analysis for select inorganic components (Reliance Laboratories Inc., Martinsburg, W.Va.) from the representative holding tanks (high and low conductivity; $0 \mathrm{mg} / \mathrm{L}$ and $800 \mathrm{mg} / \mathrm{L} \mathrm{KCl}$ ) is summarized in appendix 1. Ionized potassium values for each exposure level as determined by use of the portable meter at the onset of each experimental trial are provided in appendix 2 . Additional water-quality data collected daily from all experimental tanks throughout these trials are summarized in appendixes $3 A-3 G$ for each of the seven independent toxicity trials. Water-quality and water chemistry parameters were consistent throughout the experiments. Water temperatures were stable and comparable across experimental trials, ranging from approximately 12.7 to $13.8^{\circ} \mathrm{C}$ in the smaller replicate tanks and 11.7 to $12.8^{\circ} \mathrm{C}$ in the large recirculating system. Dissolved oxygen levels were near saturation for the duration of the experiments due to the constant aeration, and the $\mathrm{pH}$ of experimental water was mildly alkaline (approximately 7.8-8.5). Water conductivity varied among the test groups/tanks in direct proportion to the $\mathrm{KCl}$ levels added for each toxicity trial. Ionized potassium $\left(\mathrm{mg} / \mathrm{L} \mathrm{K}^{+}\right)$was generally found to be in the range of $40-50$ percent of the total $\mathrm{KCl}$ solution concentration $(\mathrm{mg} / \mathrm{L}$ or $\mathrm{ppm})$ throughout the experimental trials.

\section{Acute Toxicity of Potassium Chloride to Juvenile Salmonid Fish}

Minimal mortality (one fish) occurred across all $\mathrm{KCl}$ exposures. There was no mortality observed in the negative control groups $(0 \mathrm{mg} / \mathrm{L} \mathrm{KCl})$ for any of the trials. The single mortality was a Chinook salmon tested at $200 \mathrm{mg} / \mathrm{L} \mathrm{KCl}$ at low baseline water conductivity. The mortality occurred at the end of the trial, and was noted at the termination of the 96-hour exposure. At necropsy, this fish was generally pale, yet there were no gross lesions noted and no obvious proximate cause of death. Because this was the only mortality observed for the toxicity trials, no $\mathrm{LC}_{50}$ value could be determined for $\mathrm{KCl}$ exposure for either species at either baseline conductivity. Statistical analysis using one-way analysis of variance (ANOVA) and the Tukey-Kramer post-hoc test for paired means with $\mathrm{p}<0.05$ revealed no significant differences in mortality among any of the groups tested over the 96-hour exposures.

Abnormalities observed among the fish for each exposure trial are described in appendix 4. Sporadic noteworthy behavior was seen among the test groups. Most commonly, hyper- excitable swimming behavior was noted in one to a few fish in the various test chambers, more commonly among the Chinook salmon. Other morphological or behavioral anomalies were infrequently noted, including mild generalized hyperpigmentation or hypopigmentation, deformed opercles, increased ventilation, coughing, lethargic swimming behavior, and unusual tail flexure or undulation. Upon post-mortem examination of all test fish, no other gross abnormalities were noted. Statistical analysis of the frequency of abnormalities among treatment groups (hyper-excitability, lethargy, ventilatory changes, pigmentation status, locomotor changes, and opercular defects) was performed for each 24-hour observation interval for each of these trials. Analyses using one-way ANOVA and the Tukey-Kramer post-hoc test for paired means with $p<0.05$ revealed no significant differences among any of these parameters.

Histologically, few lesions were observed among the fish, and there were no obvious associations with $\mathrm{KCl}$ exposure levels (appendix 5). Mild epithelial lifting was noted among both species and all test groups; this change is believed to be a post-mortem artifact related to the tissue collection and processing. Histological lesions among the Chinook salmon held at low or high water conductivity included renal edema $(n=1)$, altered renal foci $(\mathrm{n}=1)$, and hepatocellular vacuolation $(\mathrm{n}=2)$; all were deemed mild in severity. Histological changes among 
the brook trout included gill epithelial hyperplasia $(n=3)$, renal mineralization/nephrocalcinosis $(\mathrm{n}=1)$, and protozoal parasites on the surface of skin or gill tissue $(n=3)$; all of these changes were also mild in severity. Epithelial lifting was noted as moderate in severity in a few individual fish among both Chinook salmon $(\mathrm{n}=3)$ and brook trout $(\mathrm{n}=1)$, somewhat above the baseline (probable artifactual) level noted throughout all other specimens. Analysis of these changes was evaluated for each test group using Fisher's exact test, and no statistical differences related to $\mathrm{KCl}$ exposure level were evident $(\mathrm{p}<0.05)$.

Chloride cell abundance was compared among the groups using one-way ANOVA with the Tukey-Kramer post-hoc test for pairs of means and $p<0.05$ (table 1; appendix 5). There were no significant differences in chloride cell abundance across the experimental treatments for either species, however, differences in abundance were noted between the fish maintained in the holding tank and a few experimental groups. For the Chinook salmon at low conductivity, chloride cell abundance was significantly greater only at $100 \mathrm{mg} / \mathrm{L}$ exposure compared with the Chinook salmon from the holding tank. For brook trout at low conductivity, chloride cell abundance was greater only for the $0 \mathrm{mg} / \mathrm{L}$ exposure group as compared to the holding tank. For brook trout at high conductivity, the same was observed for the $800 \mathrm{mg} / \mathrm{L}$ exposure group compared to the holding tank.

\section{Sublethal Physiological Impacts of Potassium Chloride to Juvenile Brook Trout - Acute Exposure}

No mortality was noted among brook trout in control or treatment groups in either high or low water conductivity. No differences in mean length or weight for fish between the control and treatment groups for either conductivity level tested were observed, based on Kruskal-Wallis statistics $(\mathrm{p}<0.05)$. During post-mortem examination, sporadic external abnormalities were noted, including frayed fins, opercular deformity, ocular hemorrhage, frayed gill, and kyphosis (spinal curvature). There were no significant differences in lesion occurrence among control and $\mathrm{KCl}$-exposed fish at either water conductivity trial, based on Fisher's exact test $(p<0.05)$.

Plasma chemistry evaluation (Kruskal-Wallis test statistic, $\mathrm{p}<0.05)$ determined that there were no significant differences in ionized calcium, hematocrit, or hemoglobin values between the control $(0 \mathrm{mg} / \mathrm{L} \mathrm{KCl})$ and $200 \mathrm{mg} / \mathrm{L} \mathrm{KCl}$ exposed groups in trials at both water conductivity levels. Additionally, there was no significant difference in plasma glucose among control and $\mathrm{KCl}$-exposed groups at the high water conductivity. Plasma potassium levels for all groups could not be determined as they all measured below the detection limit for this test (2 millimoles per liter, or mmol/L). Plasma sodium and chloride were both significantly lower in fish exposed to the $200 \mathrm{mg} / \mathrm{L}$ $\mathrm{KCl}$ compared to unexposed controls for both the high and low water conductivity experiments. Total plasma carbon dioxide $\left(\mathrm{CO}_{2}\right)$ was higher in the $\mathrm{KCl}$-exposed fish for both
Table 1. Chloride cell abundance among test groups.

[Chloride cell counts determined per five lamellae and the four adjoining inter-lamellar spaces. Mean numbers (standard error values displayed parenthetically) were determined for each species at high and low water conductivity. Baseline values are presented for additional groups of fish collected from the holding tanks to determine baseline readings from fish in the holding tank outside the scope of the experiment. Statistical differences as measured with analysis-of-variance (ANOVA) at $\mathrm{p}<0.05$ with TukeyKramer post-hoc testing were only apparent between the baseline group for each species and those experimental groups marked with an *. $\mu \mathrm{S} / \mathrm{cm}$, microsiemens per centimeter; $\mathrm{mg} / \mathrm{L}$, milligrams per liter]

\begin{tabular}{|c|c|c|c|}
\hline Species & $\begin{array}{c}\text { Water } \\
\text { conductivity } \\
\text { (value) }\end{array}$ & $\begin{array}{c}\text { Potassium } \\
\text { chloride } \\
\text { concentration, } \\
\text { in } \mathrm{mg} / \mathrm{L}\end{array}$ & $\begin{array}{l}\text { Mean number of } \\
\text { chloride cells } \\
\text { (standard error) }\end{array}$ \\
\hline \multirow{7}{*}{$\begin{array}{l}\text { Chinook } \\
\text { salmon }\end{array}$} & \multicolumn{2}{|c|}{ Baseline } & $5.1(0.28)$ \\
\hline & \multirow{3}{*}{ High $(680 \mu \mathrm{S} / \mathrm{cm})$} & 0 & $6.1(0.54)$ \\
\hline & & 100 & $7.1(0.84)$ \\
\hline & & 800 & $7.2(0.57)$ \\
\hline & \multirow{3}{*}{ Low $(150 \mu \mathrm{S} / \mathrm{cm})$} & 0 & $7.7(0.63)$ \\
\hline & & 100 & $9.2(1.12)^{*}$ \\
\hline & & 800 & $7.5(0.6)$ \\
\hline \multirow{7}{*}{$\begin{array}{c}\text { Brook } \\
\text { trout }\end{array}$} & \multicolumn{2}{|c|}{ Baseline } & $5.9(0.51)$ \\
\hline & \multirow{3}{*}{ High $(680 \mu \mathrm{S} / \mathrm{cm})$} & 0 & $7.2(0.46)$ \\
\hline & & 100 & $7.9(0.75)$ \\
\hline & & 800 & $10.0(1.02)^{*}$ \\
\hline & \multirow{3}{*}{ Low $(150 \mu \mathrm{S} / \mathrm{cm})$} & 0 & $8.7(0.96)^{*}$ \\
\hline & & 100 & $7.2(0.39)$ \\
\hline & & 800 & $7.6(0.53)$ \\
\hline
\end{tabular}

baseline conductivity levels, and plasma glucose was higher in the $\mathrm{KCl}$-exposed fish for the low water conductivity trial. Plasma osmolality was not significantly different between the unexposed and $\mathrm{KCl}$-exposed fish for either test trial. Plasma chemistry data for brook trout are summarized in table 2.

Plasma cortisol was compared between control and treatment groups following acute $\mathrm{KCl}$ exposure in either low or high conductivity water (fig. 1). In order to determine if the initial plasma cortisol concentrations between these experiments were similar, plasma cortisol concentrations were compared between control groups. No significant differences were observed between control groups. Median concentrations ranged from 34.1-35.8 nanograms per milliliter $(\mathrm{ng} / \mathrm{mL})$. Plasma cortisol was not significantly different between control and treatment groups following acute exposure to $200 \mathrm{mg} / \mathrm{L}$ $\mathrm{KCl}$ in low conductivity water $(\mathrm{p}=0.11)$. Median plasma cortisol was significantly increased following the same 24-hour exposure in high conductivity water (Mann-Whitney U test; $\mathrm{p}=0.042$ ), and there was a significant change in the probability distribution as determined by the Kolmogorov-Smirnov test $(\mathrm{p}=0.021)$. A treatment effect was evident across all groups (Kruskal-Wallis H test $(\mathrm{p}=0.009)$. 
Table 2. Plasma chemistry data for brook trout following 24-hour exposure to potassium chloride at 200 milligrams per liter.

$\left[\mathrm{KCl}\right.$, potassium chloride; $\mathrm{Na}^{+}$, sodium; $\mathrm{Cl}^{-}$, chloride; iCa, ionized calcium; $\mathrm{TCO}_{2}$, total carbon dioxide; Hct, hematocrit; $\mathrm{Hb}$, hemoglobin; $\mu \mathrm{S} / \mathrm{cm}$, microsiemens per centimeter; $\mathrm{mg} / \mathrm{L}$, milligrams per liter; mmol/L, millimoles per liter; $\mathrm{mg} / \mathrm{dL}$, milligrams per deciliter; \%, percent; g/dL, grams per deciliter; mOsm/L, milliosmoles per liter; Values shown are means with standard errors in parentheses, and statistically significant differences between the $0 \mathrm{mg} / \mathrm{L}$ and $200 \mathrm{mg} / \mathrm{L}$ exposure groups are indicated with an * (Kruskal-Wallis test statistic with $\mathrm{p}<0.05)$ ]

\begin{tabular}{|c|c|c|c|c|c|c|c|c|c|}
\hline $\begin{array}{l}\text { Baseline water } \\
\text { conductivity } \\
\text { (value) }\end{array}$ & $\begin{array}{c}\mathrm{KCl}, \\
\text { in mg/L }\end{array}$ & $\begin{array}{c}\mathrm{Na}^{+}, \\
\text {in } \mathrm{mmol} / \mathrm{L}\end{array}$ & $\begin{array}{c}\mathrm{Cl}^{-}, \\
\text {in } \mathrm{mmol} / \mathrm{L}\end{array}$ & $\begin{array}{c}\text { iCa, } \\
\text { in } \mathrm{mmol} / \mathrm{L}\end{array}$ & $\begin{array}{c}\mathrm{TCO}_{2^{\prime}} \\
\text { in } \mathrm{mmol} / \mathrm{L}\end{array}$ & $\begin{array}{l}\text { Glucose, } \\
\text { in } \mathrm{mg} / \mathrm{dL}\end{array}$ & $\begin{array}{l}\text { Hct, } \\
\text { in \% }\end{array}$ & $\begin{array}{c}\mathrm{Hb}, \\
\text { in } \mathrm{g} / \mathrm{dL}\end{array}$ & $\begin{array}{l}\text { Osmolality } \\
\text { in } \mathrm{m0sm} / \mathrm{L}\end{array}$ \\
\hline \multirow{2}{*}{$\begin{array}{c}\text { Low } \\
(150 \mu \mathrm{S} / \mathrm{cm})\end{array}$} & 0 & $143.6(0.9)$ & $127.8(0.7)$ & $1.84(0.03)$ & $10.9(0.2)$ & $109.3(5.6)$ & $42.2(1.5)$ & $14.4(0.5)$ & $309.8(2.0)$ \\
\hline & 200 & $141.1(0.8)^{*}$ & $124.5(0.9)^{*}$ & $1.86(0.02)$ & $11.6(0.3)^{*}$ & $134.3(6.8)^{*}$ & $46.0(1.4)$ & $15.6(0.5)$ & $306.6(1.9)$ \\
\hline \multirow{2}{*}{$\begin{array}{c}\text { High } \\
(680 \mu \mathrm{S} / \mathrm{cm})\end{array}$} & 0 & $141.8(0.8)$ & $124.0(0.7)$ & $1.72(0.04)$ & $11.1(0.3)$ & $153.2(8.7)$ & $43.8(1.3)$ & $14.9(0.5)$ & $298.9(1.5)$ \\
\hline & 200 & $138.2(1.1)^{*}$ & $117.6(1.2)^{*}$ & $1.74(0.07)$ & $13.9(0.5)^{*}$ & $176.0(12.4)$ & 48.0 (1.9) & $16.3(0.6)$ & $291.7(2.8)$ \\
\hline
\end{tabular}

Brook trout

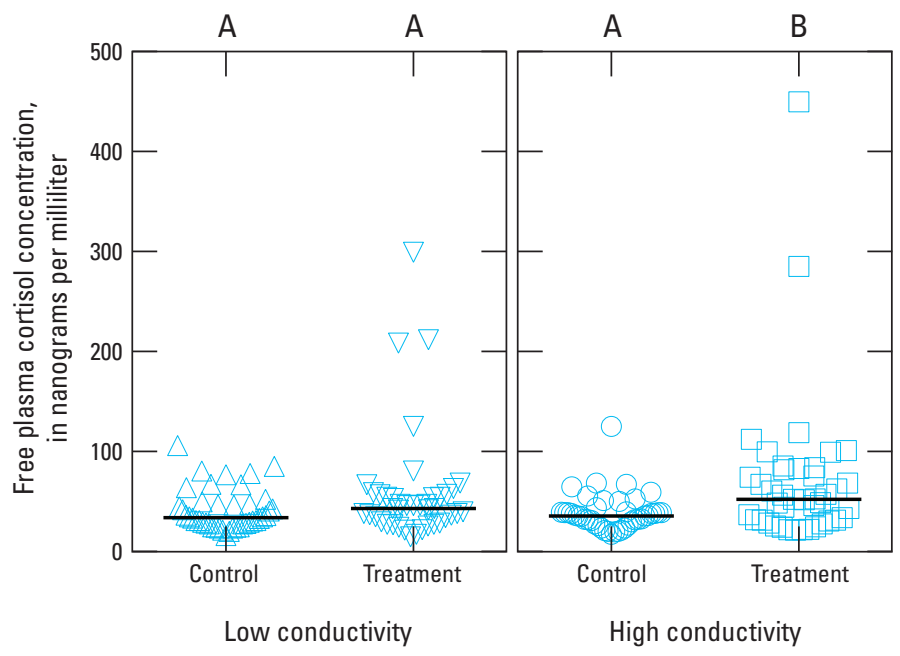

Chinook salmon

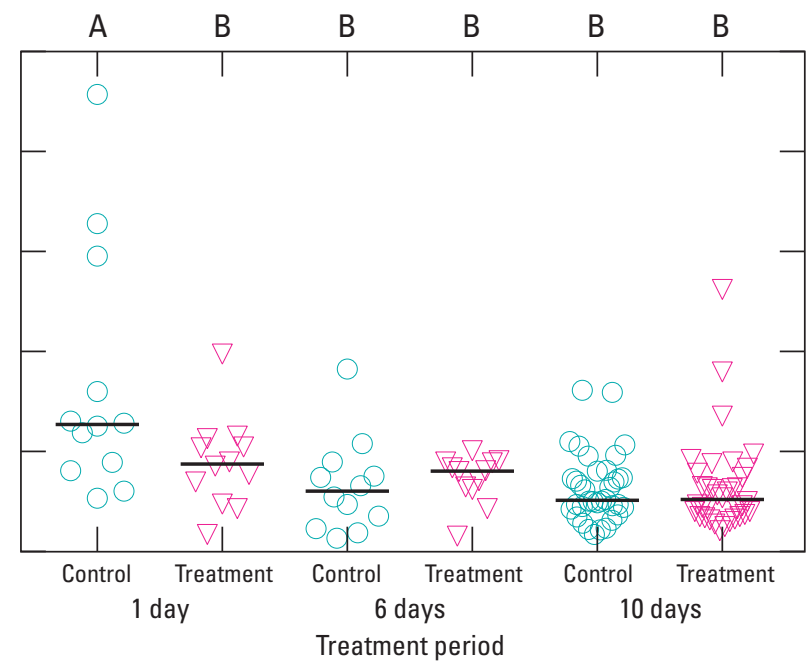

Figure 1. Plasma cortisol values for brook trout and Chinook salmon exposed to 0 and 200 milligrams per liter (mg/L) of potassium chloride. Plasma cortisol was not significantly different among brook trout between control and treatment groups following acute exposure to $200 \mathrm{mg} / \mathrm{L}$ of potassium chloride (KCI) in low conductivity water, but median plasma cortisol was significantly increased following the same 24-hour exposure in high conductivity water. Among the Chinook salmon, plasma cortisol decreased across groups over time during the course of this experiment, and median plasma cortisol was significantly higher in control fish compared to KCL-exposed fish at the 24-hour time point. Horizontal bars indicate the median. Treatment denoted with the same capital letter are not significantly different $(p \leq 0.05)$. 


\section{Sublethal Physiological Impacts of Potassium Chloride to Juvenile Chinook Salmon- Subchronic Exposure}

No mortality was noted among Chinook salmon control or treatment groups during the exposure trial. There were no differences in mean fish length or weight between the control and treatment groups for either conductivity level based on Kruskal-Wallis statistics $(\mathrm{p}<0.05)$. During post-mortem examination, sporadic abnormalities were noted, which included mild ocular hemorrhage and renal mineralization. There were no significant differences in the occurrence of lesions among control and $\mathrm{KCl}$-exposed fish based on Fisher's exact test at $\mathrm{p}<0.05$.

Plasma chemistry parameters were evaluated for changes over the course of the exposure for each test group sampled at 1 day and 10 days (table $3 A$ ). These parameters were also evaluated for differences between the $0 \mathrm{mg} / \mathrm{L}$ and $200 \mathrm{mg} / \mathrm{L}$ exposures at each distinct time interval (table $3 B$ ). Analyses were performed with the Kruskal-Wallis test statistic at $\mathrm{p}<0.05$. Again, plasma potassium levels for all groups could not be determined as they all were below the detection limit for this test $(2 \mathrm{mmol} / \mathrm{L})$. Four of the plasma chemistry parameters as well as hematocrit and hemoglobin changed significantly over the course of the experiment for the unexposed control group $(0 \mathrm{mg} / \mathrm{L})$ : plasma sodium, chloride, and ionized calcium decreased whereas plasma glucose, hematocrit, and hemoglobin all increased from day 1 to day 10 . Only total carbon dioxide $\left(\mathrm{TCO}_{2}\right)$ levels were significantly increased from day 1 to day 10 for the test group exposed to $200 \mathrm{mg} / \mathrm{L} \mathrm{KCl}$. Significant differences between the 0 and the $200 \mathrm{mg} / \mathrm{L}$ exposure groups also were noted among three of the plasma chemistry parameters, each at two distinct time intervals: plasma sodium was higher in the $\mathrm{KCl}$ exposure group at days 6 and 10; plasma chloride was lower in the exposure group at days 1 and 6; and plasma glucose was higher in the exposure group at days 1 and 6 . In addition, both hematocrit and hemoglobin were lower for the $200 \mathrm{mg} / \mathrm{L}$ exposure group compared to the $0 \mathrm{mg} / \mathrm{L}$ control group on day 10.

Table 3A. Plasma chemistry data for Chinook salmon over time for 0 milligrams per liter and 200 milligrams per liter potassium chloride exposure groups.

$\left[\mathrm{KCl}\right.$, potassium chloride; $\mathrm{Na}^{+}$, sodium; $\mathrm{Cl}^{-}$, chloride; iCa, ionized calcium; $\mathrm{TCO}_{2}$, total carbon dioxide; Hct, hematocrit; $\mathrm{Hb}$, hemoglobin; mg/L, milligrams per liter; mmol/L, millimoles per liter; mg/dL, milligrams per deciliter; \%, percent; g/dL, grams per deciliter; mOsm/L, milliosmoles per liter; Values shown are means with standard errors in parentheses, and statistically significant differences between the 1-day and 10-day measured parameters for the $0 \mathrm{mg} / \mathrm{L}$ and $200 \mathrm{mg} / \mathrm{L}$ exposure groups are indicated with an * next to the mean for the 10-day measured value in each test group (Kruskal-Wallis test statistic with $\mathrm{p}<0.05)]$

\begin{tabular}{|c|c|c|c|c|c|c|c|c|}
\hline Test period & $\begin{array}{c}\mathrm{Na}^{+}, \\
\text {in } \mathrm{mmol} / \mathrm{L}\end{array}$ & $\begin{array}{c}\mathrm{Cl}^{-}, \\
\text {in } \mathrm{mmol} / \mathrm{L}\end{array}$ & $\begin{array}{c}\text { iCa, } \\
\text { in } \mathrm{mmol} / \mathrm{L}\end{array}$ & $\begin{array}{c}\mathrm{TCO}_{2} \\
\text { in } \mathrm{mmol} / \mathrm{L}\end{array}$ & $\begin{array}{l}\text { Glucose, } \\
\text { in } \mathrm{mg} / \mathrm{dL}\end{array}$ & $\begin{array}{l}\text { Het, } \\
\text { in } \%\end{array}$ & $\begin{array}{c}\mathrm{Hb}, \\
\text { in } \mathrm{g} / \mathrm{dL}\end{array}$ & $\begin{array}{l}\text { Osmolality, } \\
\text { in } \mathrm{m} 0 \mathrm{sm} / \mathrm{L}\end{array}$ \\
\hline \multicolumn{9}{|c|}{$0 \mathrm{mg} / \mathrm{L} \mathrm{KCl}$} \\
\hline Day 10 & $140.6(0.6)^{*}$ & $124.2(1.2)^{*}$ & $1.94(0.04)^{*}$ & $12.5(0.3)$ & $73.1(3.2)^{*}$ & $48.5(1.6)^{*}$ & $16.5(0.5)^{*}$ & $299.6(2.0)$ \\
\hline \multicolumn{9}{|c|}{$200 \mathrm{mg} / \mathrm{L} \mathrm{KCl}$} \\
\hline
\end{tabular}

Table 3B. Plasma chemistry for Chinook salmon throughout the 10-day potassium chloride exposure trial.

$\left[\mathrm{KCl}\right.$, potassium chloride; $\mathrm{Na}^{+}$, sodium; $\mathrm{Cl}^{-}$, chloride; iCa, ionized calcium; $\mathrm{TCO}_{2}$, total carbon dioxide; Hct, hematocrit; $\mathrm{Hb}$, hemoglobin; mg/L, milligrams per liter; mmol/L, millimoles per liter; mg/dL, milligrams per deciliter; \%, percent; g/dL, grams per deciliter; mOsm/L, milliosmoles per liter; Values shown are means with standard errors in parentheses, and statistically significant differences between the $0 \mathrm{mg} / \mathrm{L}$ and $200 \mathrm{mg} / \mathrm{L}$ exposure groups are indicated with an * next to the mean for the $200 \mathrm{mg} / \mathrm{L}$ cell for each individual time period $(1,6$, or 10 days; Kruskal-Wallis test statistic with $\mathrm{p}<0.05)$ ]

\begin{tabular}{|c|c|c|c|c|c|c|c|c|c|}
\hline Test period & $\begin{array}{c}\mathrm{KCl}, \\
\text { in mg/L }\end{array}$ & $\begin{array}{c}\mathrm{Na}^{+}, \\
\text {in } \mathrm{mmol} / \mathrm{L}\end{array}$ & $\begin{array}{c}\mathrm{Cl}^{-}, \\
\text {in } \mathrm{mmol} / \mathrm{L}\end{array}$ & $\begin{array}{c}\text { iCa, } \\
\text { in } \mathrm{mmol} / \mathrm{L}\end{array}$ & $\begin{array}{c}\mathrm{TCO}_{2^{\prime}} \\
\text { in } \mathrm{mmol} / \mathrm{L}\end{array}$ & $\begin{array}{l}\text { Glucose, } \\
\text { in } \mathrm{mg} / \mathrm{dL}\end{array}$ & $\begin{array}{l}\text { Hct, } \\
\text { in } \%\end{array}$ & $\begin{array}{c}\mathrm{Hb}, \\
\text { in } \mathrm{g} / \mathrm{dL}\end{array}$ & $\begin{array}{l}\text { Osmolality, } \\
\text { in } \mathrm{m} 0 \mathrm{sm} / \mathrm{L}\end{array}$ \\
\hline Day 1 & 0 & $144.1(1.0)$ & $127.3(0.7)$ & $1.79(0.02)$ & $11.9(0.3)$ & $63.4(3.9)$ & $40.3(1.0)$ & $13.7(0.3)$ & $295.3(1.5)$ \\
\hline \multirow{2}{*}{ Day 6} & 0 & $143.1(0.4)$ & $127.1(0.6)$ & $1.74(0.02)$ & $11.2(0.3)$ & $55.5(2.4)$ & $41.1(1.4)$ & $14.2(0.4)$ & $301.4(3.0)$ \\
\hline & 200 & $144.9(0.4)^{*}$ & $125.1(0.6)^{*}$ & $1.82(0.03)$ & $11.0(0.3)$ & $67.2(3.9)^{*}$ & $40.2(1.3)$ & $13.7(0.4)$ & $300.0(2.4)$ \\
\hline
\end{tabular}


Plasma osmolality was not significantly different between the unexposed and $\mathrm{KCl}$-exposed fish at the 1-, 6-, or 10-day time interval, nor did plasma osmolality differ significantly between day 1 and day 10 of the exposures for either the $0 \mathrm{mg} / \mathrm{L}$ or $200 \mathrm{mg} / \mathrm{L}$ exposure groups.

Plasma cortisol concentrations were compared across treatments and time for the $\mathrm{KCl}$ exposures for Chinook salmon (fig. 1). Significant differences were identified across all groups (Kruskal-Wallis $\mathrm{H}$ test; $\mathrm{p}=0.009$ ). Median plasma cortisol was significantly higher in control fish $(170.3 \mathrm{ng} / \mathrm{mL})$ compared to $\mathrm{KCl}$-exposed fish $(89.0 \mathrm{ng} / \mathrm{mL})$ at the 24 -hour time point (Kolmogorov-Smirnov test; $p=0.034$ ). In general, plasma cortisol decreased across groups over time during the course of this experiment indicating that the increased plasma cortisol at the 24-hour time point reflected handling stress initiated at time zero. By day 10, median plasma cortisol was 52.7 and $53.4 \mathrm{ng} / \mathrm{mL}$ between the control and treated groups, respectively. The analysis of resting plasma cortisol in Chinook salmon indicated great variability $(14.4-80.4 \mathrm{ng} / \mathrm{mL}$; median, 57.3).

\section{Acute Toxicity of Potassium Chloride to Invertebrate Forage of Salmonid Fish}

Whereas mortality was observed among the chironomids including both control and $\mathrm{KCl}$ treatment groups, no significant trends in mortality related to the $\mathrm{KCl}$ exposure levels were noted. Assessment of mortality was confounded by the cannibalistic or scavenging behavior of the chironomid larvae, as observed by the disappearance of whole specimens or portions of specimens from the test chambers. ANOVA (one-way, $\mathrm{p}<0.05$ ) did not show any significant differences in mortality among the test concentrations (fig. 2).

Mortality among the daphniids showed significant differences among test groups for each observation interval ( 2 hours, 4 hours, 24 hours, 48 hours) as evaluated with the Kruskal-Wallis test statistic at $\mathrm{p}<0.05$ (fig. 3). Calculation of $\mathrm{KCl} \mathrm{LC}{ }_{50}$ concentrations was performed using log probit analysis (Miller and Tainter, 1944) for the daphniids. The $\mathrm{LC}_{50}$ decreased in concentration value with increasing time, so that the 2-hour exposure $\mathrm{LC}_{50}$ was approximately $1,375 \mathrm{mg} / \mathrm{L}$

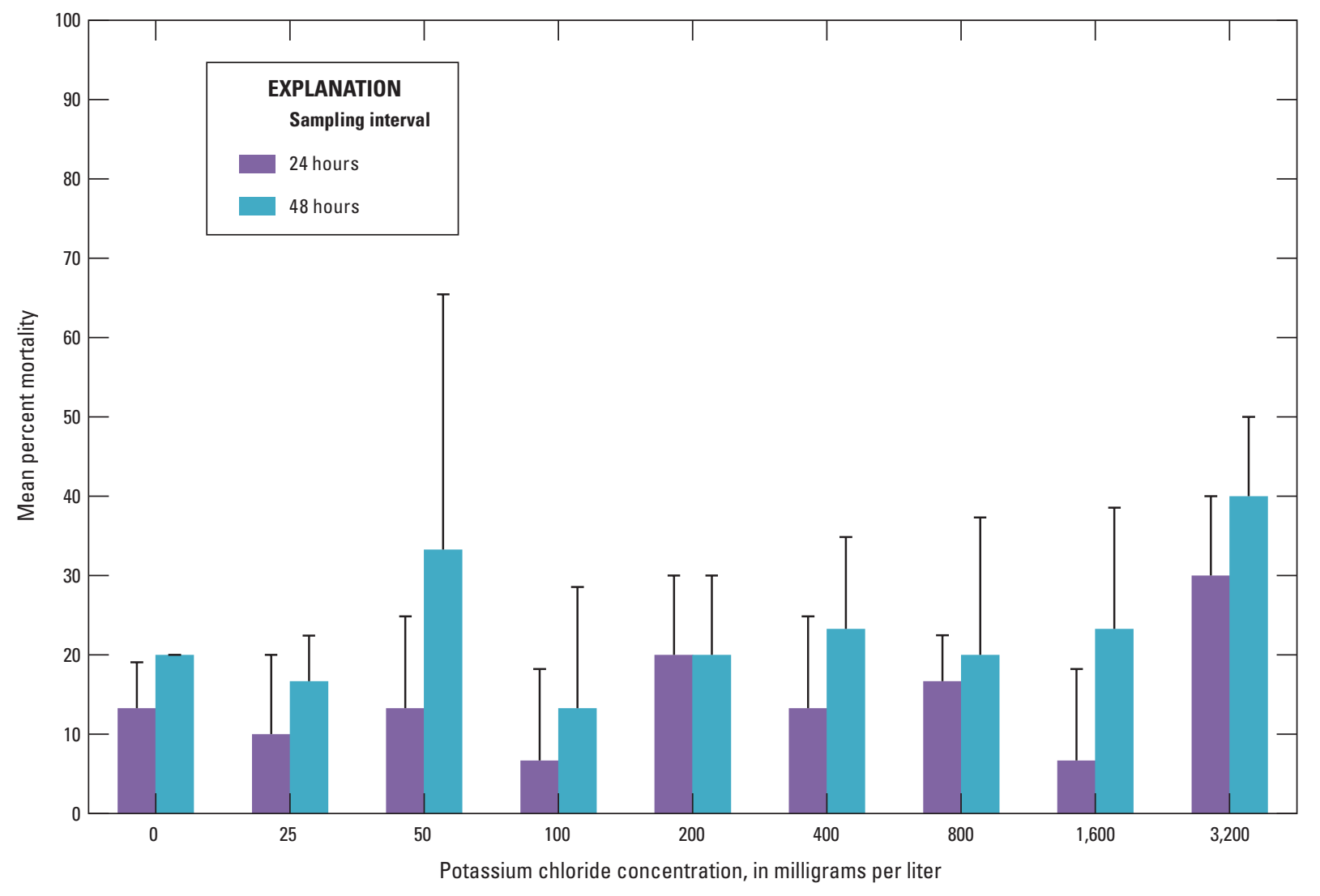

Figure 2. Mortality of chironomid larvae (bloodworms) during toxicity testing with potassium chloride exposures of 0-3,200 milligrams per liter. Mean percent mortality of chironomids (with standard deviation bars) for all three replicates at each test concentration for 24-hour (h) and 48-h intervals. No mortality was noted at $2 \mathrm{~h}$ and $4 \mathrm{~h}$. 
whereas the 48-hour exposure $\mathrm{LC}_{50}$ was calculated as $196 \mathrm{mg} / \mathrm{L}$ (fig. 4; appendix 6).

Mortality was also observed among the crayfish (fig. 5). Cannibalism occurred at all test concentrations except the $0 \mathrm{mg} / \mathrm{L}$ exposure group at or after 24 hours; therefore, half or more of the replicates from each test concentration were removed from the experiment beyond this point. As a result, differences among each test concentration were only evaluated through the 9-hour and 24-hour exposures. No mortality was evident at the 9-hour test interval among any test groups, but a significant difference $(\mathrm{p}<0.05)$ among groups was noted at 24 hours by use of one way-ANOVA $(p=0.026)$. The
Tukey-Kramer post-hoc test identified a significant difference only between the $0 \mathrm{mg} / \mathrm{L}$ and the $800 \mathrm{mg} / \mathrm{L}$ exposure groups, with decreased survival among the $800 \mathrm{mg} / \mathrm{L}$ exposure group. A total of seven crayfish from the $800 \mathrm{mg} / \mathrm{L}$ concentration and one crayfish from the $1,600 \mathrm{mg} / \mathrm{L}$ concentration were presumed dead and removed from the experimental tanks to freshwater holding tanks without $\mathrm{KCl}$. Within 24 hours, four of the seven crayfish from the $800 \mathrm{mg} / \mathrm{L}$ exposure group recovered their righting reflex and response to tactile stimuli. The crayfish from the $1,600 \mathrm{mg} / \mathrm{L}$ exposure group did not recover and was presumed dead.

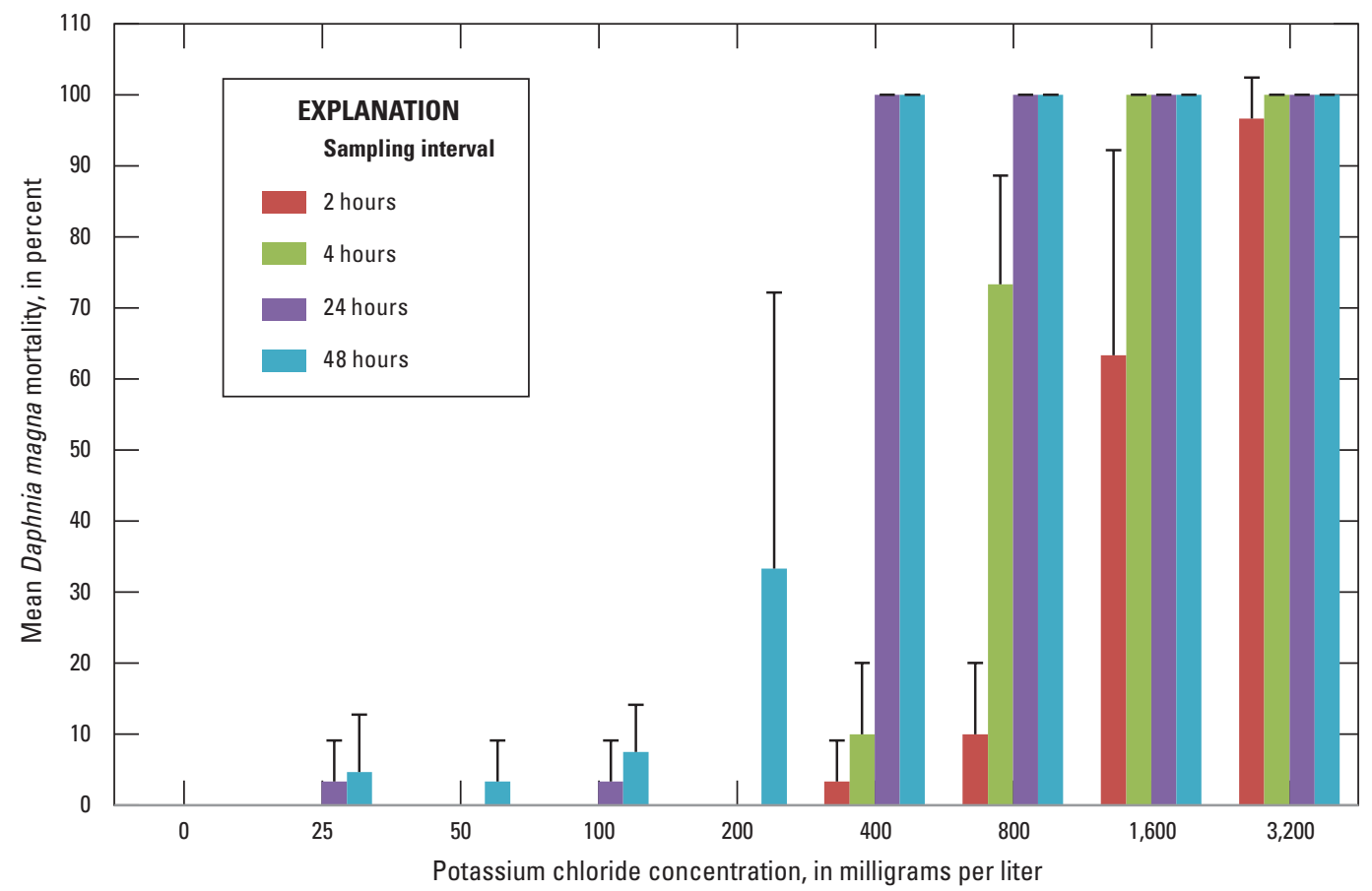

Figure 3. Mortality of Daphnia magna during toxicity testing with potassium chloride exposures of 0-3,200 milligrams per liter. Mean percent mortality of Daphnia (with standard deviation bars) for all three replicates are given for each test concentration and test interval. 


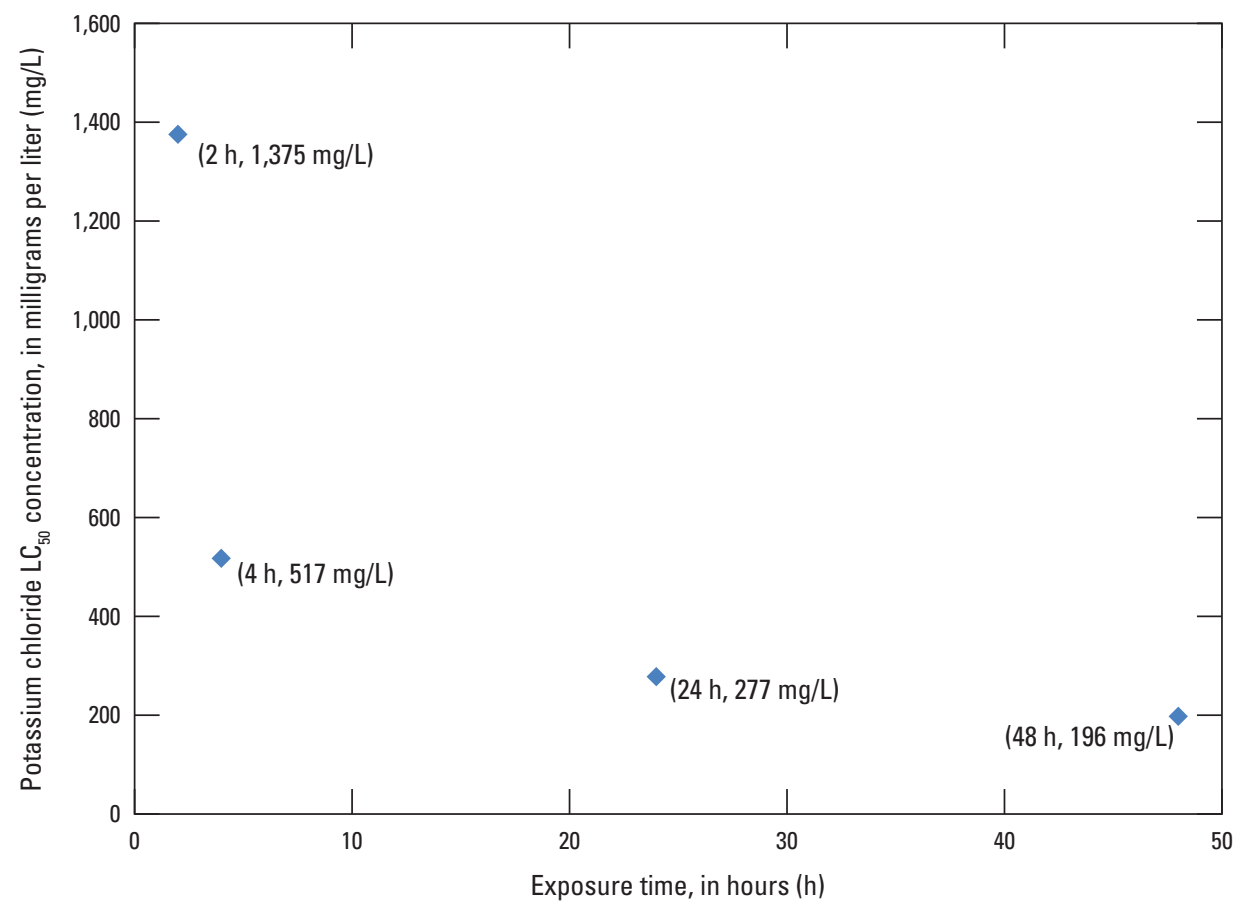

Figure 4. Lethal concentration $\left(\mathrm{LC}_{50}\right)$ values for daphniid exposure to potassium chloride. Values were derived by use of log probit analysis, and demonstrate that the $L C_{50}$ decreases with increasing time of exposure. $\mathrm{LC}_{50}$ values are shown in milligrams per liter for 2, 4, 24, and 48 hours.

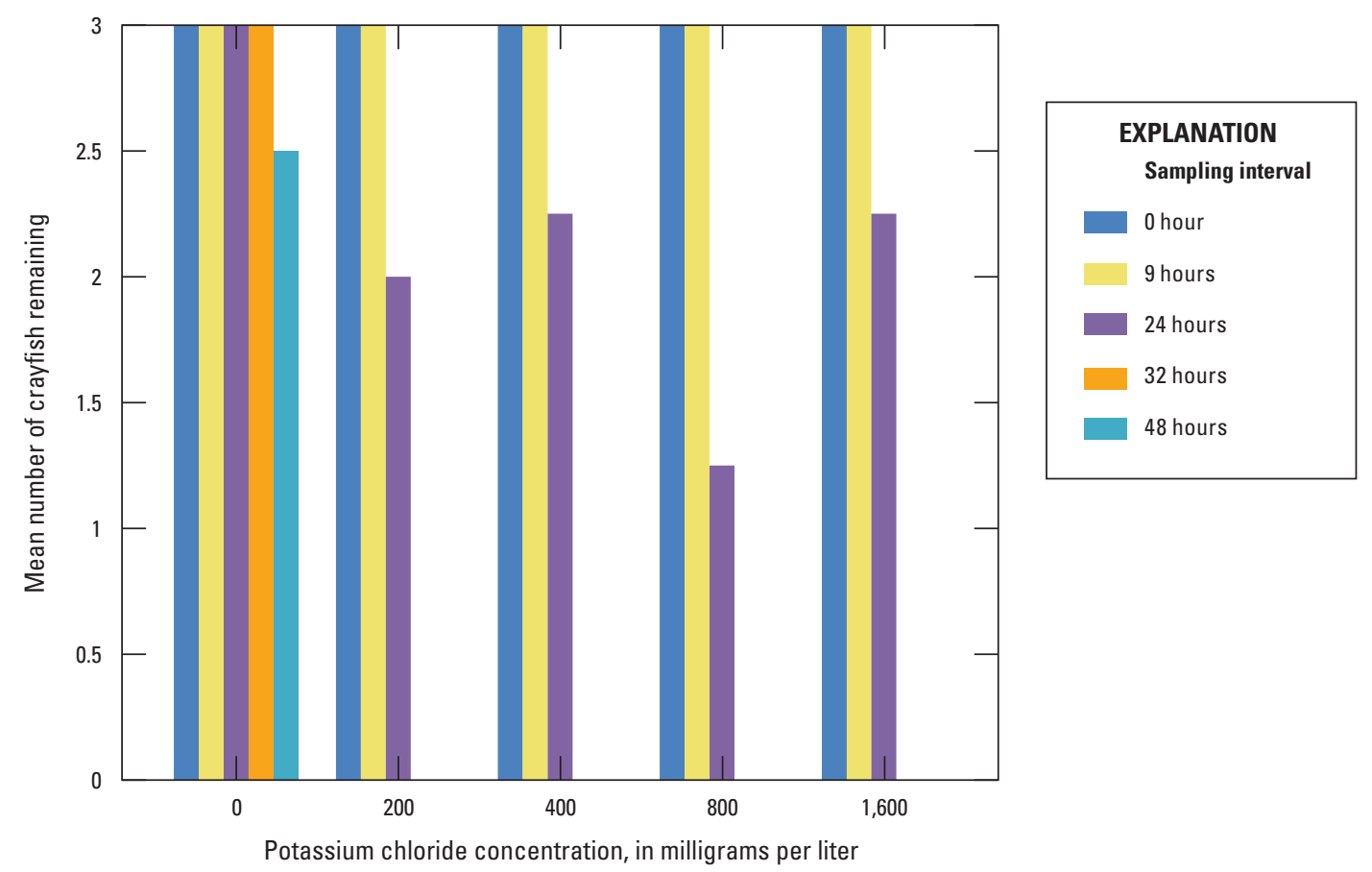

Figure 5. Acute exposure to potassium chloride in crayfish. Mean survival (three crayfish per replicate) at each interval (h, hours) for each potassium chloride concentration. No data are provided for replicates removed from the study due to cannibalism at 32 and $48 \mathrm{~h}$. 


\section{Interpretations and Conclusions}

Based upon the acute toxicity testing of $\mathrm{KCl}$ using both juvenile brook trout and juvenile Chinook salmon, acute lethal effects of potash on these salmonids at these life stages are not expected at concentrations commonly utilized to control invasive dreissenid mussels (100 mg/L). Exposure concentrations of as much as $800 \mathrm{mg} / \mathrm{L} \mathrm{KCl}$, eight times greater than the dose of $\mathrm{KCl}$ used as a molluscicide, were applied to these fish in static systems for 96 hours; there was no evidence of mortality attributable to $\mathrm{KCl}$ exposure among either species. On the basis of this observation, it is clear that the lethal concentration $\left(\mathrm{LC}_{50}\right)$ is well above the $\mathrm{KCl}$ concentrations used in this study. The no observed effect concentration (NOEC) for $\mathrm{KCl}$ under these test conditions is also beyond the scope of $\mathrm{KCl}$ concentrations used in this study.

Behavioral or gross morphological effects on these fish from $\mathrm{KCl}$-based molluscicide applications at levels up to $800 \mathrm{mg} / \mathrm{L}$ were also not indicated within the scope of this study. There were no sublethal behavioral effects noted for either species in association with the $\mathrm{KCl}$ exposures through the $800 \mathrm{mg} / \mathrm{L}$ concentrations tested. Behavioral changes related to respiration and locomotion and noted infrequently among the fingerlings of both species were not associated with $\mathrm{KCl}$ concentration, nor were they statistically different among the test groups. Similarly, mild gross morphological changes including pigmentation differences and opercular defects were noted, however, were neither consistent within certain test groups nor statistically different among groups. In addition, necropsy of the brook trout assessed for sublethal physiological impacts (24-hour exposure at $200 \mathrm{mg} / \mathrm{L} \mathrm{KCl}$ ) revealed no morphological changes associated with $\mathrm{KCl}$ exposure.

Histological examination of tissues was utilized to determine the potential for overt or subtle microscopic morphological changes to provide indications of physiological impairment related to $\mathrm{KCl}$ exposure. In particular, changes to osmoregulatory and ionoregulatory organs and tissues (skin, gill, excretory kidney) could be anticipated with exposure to high concentrations of inorganic salts. Histologically, few changes were evident among these fish. There was no statistical significance attributed to any of the changes, and no apparent correlation to changes at either 100 or $800 \mathrm{mg} / \mathrm{L} \mathrm{KCl}$ exposure compared to the $0 \mathrm{mg} / \mathrm{L} \mathrm{KCl}$ exposure control fish. Because of the lack of histological findings among specimens held at these $\mathrm{KCl}$ concentrations among both species, fish tissue samples collected from the other specimens were not processed for evaluation.

Quantitative histological evaluation of chloride cell presence along the base of the lamellae in the gill epithelium was included in the histological analysis, as the mitochondrionrich chloride cells play an important role in ionoregulation, and chloride cell proliferation is a common response to environmental challenges to fish involving ionoregulatory responses (Perry, 1998). For both marine and freshwater teleosts, chloride cells are sites of ion transport processes through various mechanisms such as $\mathrm{Na}^{+} / \mathrm{K}^{+} /$ATPase, electrogenic proton extrusion, and anionic exchange (Evans and others, 2005), and chloride cell numbers reflect metabolic activity in gill tissue (Perry and Walsh, 1989). Physiological stress posed by elevated concentrations of environmental salts such as $\mathrm{KCl}$ may therefore be expected to result in increased numbers of chloride cells in the branchial epithelium; however, this was generally not observed in this study. Whereas significant differences in chloride cell numbers were observed for both species, these differences were seen between fish maintained in the holding tanks and fish in three of the different experimental groups (table 1). Differences were inconsistent in that they were noted in three of four experimental trials at both baseline conductivity levels for the test water and among three $\mathrm{KCl}$ exposure levels $(0,100$, and $800 \mathrm{mg} / \mathrm{L})$. These differences, if physiologically relevant, represented increased chloride cell numbers in response to other water chemistry parameters in flowing holding water compared to static test water rather than changes attributable to $\mathrm{KCl}$ exposures.

Plasma chemistry parameters provide further information relative to the overall health of fish, and have longstanding use as clinical indicators of disease among salmonid fish (Hille, 1982). However, there may still be considerable variability among normal or reference range for blood parameters related to environmental conditions and life history variables for a given species of salmonid fish (Hille, 1982; Holmes and Donaldson, 1969). Statistical differences were noted among some of these clinical chemistry parameters (such as plasma sodium and chloride) when compared between $\mathrm{KCl}$-exposed and unexposed fish. However, these differences do not necessarily indicate associated pathological impacts of $\mathrm{KCl}$. The plasma chemistry values, though statistically distinct between the groups, still appear to fall within established ranges of "normal" values as reported in the literature (Holmes and Donaldson, 1969). For instance, plasma sodium values in this study were lower in the brook trout exposed to $200 \mathrm{mg} / \mathrm{L}$ $\mathrm{KCl}$ compared to the unexposed control fish at both high and low water conductivity levels. Although statistically different, these mean plasma sodium values were still close (within a few millimoles per liter) and were comparable to previously reported normal values or reference ranges for trout in freshwater (Holmes and Donaldson, 1969). Thus, although the differences in some plasma electrolyte values between groups were statistically significant, they were not sufficiently divergent to indicate impactful physiological differences. There is an inherent challenge related to the interpretation of such results, and differences in one such parameter must be considered in light of the remainder of the clinical data collected to determine their meaning.

Similar to the blood chemistry results, although statistically significant differences in plasma cortisol associated with $\mathrm{KCl}$ treatments were observed, the biological ramifications of these differences are not clear. The $\mathrm{KCl}$ treatment of brook trout led to increased plasma cortisol in high conductivity water. Differences in plasma cortisol among Chinook salmon, however, did not follow this same trend as cortisol was 
initially higher among the unexposed control fish and their cortisol levels decreased over time during the 10-day trial.

Plasma glucose, another non-specific indicator of physiological stress among vertebrates, was also higher among the $\mathrm{KCl}$-exposed fish compared to control fish for brook trout tested at low water conductivity for 24 hours and for Chinook salmon during 24 hours and 6 days of exposure. Consistent with the other blood chemistry changes noted, the differences in glucose levels between unexposed and $\mathrm{KCl}$-exposed fish for each species were not extreme and are well within the scope of normal physiological response to an environmental stressor (Wagner and Congleton, 2004; Densmore and Panek, 2013). By comparison, a greater disparity in blood glucose levels were noted between the unexposed control Brook trout held at low (150 microsiemens per centimeter, or $\mu \mathrm{S} / \mathrm{cm})$ water conductivity $(109.3 \mathrm{~g} / \mathrm{dL})$ and unexposed control brook trout held at high $(680 \mu \mathrm{S} / \mathrm{cm})$ water conductivity $(153.2 \mathrm{~g} / \mathrm{dL})$.

Significant differences in physiological stress responses between brook trout and Chinook salmon may be confounded by the genetic histories and life histories of the two tested species. The brook trout used in this study were obtained from an aquaculture facility that breeds strains of fish for commercial fish production. Previous research has shown that aquaculture strains of fish species are more resilient and recover more quickly from handling and tank confinement than wild fish (Huntingford, 2004; Overli and others, 2005). The Chinook salmon utilized in this study came from a New York Department of Environmental Conservation hatchery, which spawns wild broodstock that swim upriver into holding areas during the natural spawning season; they have not been "domesticated" or bred in captivity for several generations. Presumably, they are less adapted to confinement in captivity (Stickney, 1994). In addition, most brook trout populations are stenohaline salmonids that are adapted to cold, very clean freshwater (Benke, 2002), whereas Chinook salmon are an anadromous species that spawn in freshwater, travel downriver and mature in saltwater, and return to natal freshwater rivers to spawn (National Oceanic and Atmospheric Administration Fisheries, 2016). Anadromous species are euryhaline, and are adaptable to a wide range of salinity or ion concentrations. Changes in ion concentrations are less likely to affect Chinook salmon, as indicated by the increase in cortisol immediately following $\mathrm{KCl}$ addition, which decreases over exposure time.

Although few to no impacts were noted among the salmonid fish that may indicate mortality or significant physiological impairment resulting from $\mathrm{KCl}$ exposure, the data derived from the invertebrate exposure trials indicates otherwise. The chironomid larvae exposures were largely inconclusive because of cannibalistic behavior among the various test groups; mortality could not be definitively attributed to $\mathrm{KCl}$ exposure. Furthermore, no statistical differences in mortality among the groups were present to indicate a potential impact of acute $\mathrm{KCl}$ exposure on survival. Daphniid exposure trials, however, resulted in statistically significant differences in mortality among the test groups with higher mortality evident among the higher exposure concentrations (figs. 3 and 4) and a $\mathrm{LC}_{50}$ calculated as $196 \mathrm{mg} / \mathrm{L}$ for 48 hours of exposure. Previous application of potash as a KCl-based molluscicide was at concentrations of $100 \mathrm{mg} / \mathrm{L}$, less than half of this calculated $\mathrm{LC}_{50}$ value (Virginia Department of Game and Inland Fisheries, 2005). In light of the target application of potash as a molluscicide directed against the veliger stage of dreissenid mussels, significant mortality among sensitive aquatic invertebrates, such as daphniids, is not unexpected.

Crayfish, the other crustacean species examined in this study, also appeared to show some degree of sensitivity to high concentrations of $\mathrm{KCl}$. Crayfish mortality occurred in test groups exposed to $\mathrm{KCl}$, particularly among the higher concentrations, at 24 hours and beyond, although the mortality rate was not specifically dose-dependent. Cannibalism confounded the interpretation of results, particularly beyond 24-hour exposure. Immobilization of many specimens held at higher concentrations of $\mathrm{KCl}$ ( 800 and $1,600 \mathrm{mg} / \mathrm{L}$ ), mimicking the appearance of death through both loss of righting reflex and failure to respond to tactile stimuli, was also of interest. Half of the specimens presumed to be dead from these test groups were able to completely recover in freshwater within 24 hours. Even complete recovery from this level of immobilization, however, presents a cause for concern for the survival of individual animals, as crayfish would be potentially vulnerable to predation and other environmental pressures if they were unable to respond accordingly for a substantial period of time. Causality related to this finding in this experiment was not determined, but it is likely that the immobility was related to disruption of neuromuscular function through altered ionic potential across cell membranes. Crayfish possess a stretch receptor organ, which functions analogously to the muscle spindle in vertebrates (Rydqvist and others, 2007), and disruption of this organ's function and resultant paralysis may possibly be attributed to high environmental concentrations of ions $\left(\mathrm{K}^{+}\right.$in particular). Further investigation related to this phenomenon could help discern the causality of the immobility, and whether prolonged exposure to lower doses of $\mathrm{KCl}$ may also represent a threat to crayfish or other invertebrate forage species.

\section{Selected References}

Behnke, R.J., 2002, Brook Trout, Salvelinus fontinalis, in Tomelleri, J.R., ed., Trout and salmon of North America: New York, New York, The Free Press, p. 275-280.

Carey, J.B., and McCormick, S.D., 1998, Atlantic salmon smolts are more responsive to an acute handling and confinement stress than parr: Aquaculture, v. 168, p. 237-253, accessed March 1, 2016, at http://www.bio.umass.edu/biology/mccormick/pdf/aq\%2098\%20stress\%20responsiveness. pdf. 
Densmore, C.L., Iwanowicz, L., Henderson, A., Blazer, V.S., Reed-Grimmett, B.M., and Sanders, L.R., 2018, Toxicity of potassium chloride, active compound in the molluscicide potash, on salmonid fishes and their forage base (Leetown Science Center, 2018): U.S. Geological Survey data release, https://doi.org/10.5066/F7HQ3Z5G.

Densmore, C.L., and Panek, F.M., 2013, Effects of depletion sampling by standard three-pass pulsed DC electrofishing on blood chemistry parameters on fishes from Appalachian streams: North American Journal of Fisheries Management, v. 32 , no. 2, p. 298-306, accessed June 28 , 2017, at https:// doi.org/10.1080/02755947.2012.758203.

Evans, D.H., Piermarani, P.M., and Choe, K.P., 2005, The multifunctional fish gill-Dominant site of gas exchange, osmoregulation, acid-base regulation, and excretion of nitrogenous waste: Physiological Reviews, v. 85, no. 1 , p. 97-177, accessed August 11, 2017, at https://www.ncbi. nlm.nih.gov/pubmed/15618479.

Fisher, S.W., Stromberg, P., Bruner, K.A., and Boulet, L.D., 1991, Molluscicidal activity of potassium to the zebra mussel, Dreissena plymorphia: toxicity and mode of action: Aquatic Toxicology, v. 20, no. 4, p. 219-234, accessed July 1, 2015, at https://doi.org/10.1016/0166445X(91)90061-D.

Getchell, R.G., and Bowser, P.R., 2006, Ecology of Type E botulism within dressenid mussel beds: Aquatic Invaders, v. 17, no. 2, p. 1-8, accessed February 1, 2018, at https:// www.researchgate.net/profile/Rodman_Getchell/publication/285474802_Ecology_of_type_E_boltulism_within dressenid_mussel_beds/liks/56634d3708ae192bbf8eefba. pdf. doi.org/10.1016/0166-445X(91)90061-D.

Hille, S., 1982, A literature review of the blood chemistry of rainbow trout, Salmo gairdneri Rich: Journal of Fish Biology, v. 20, no. 5, p. 535-569, accessed February 10, 2017, at https://doi.org/10.1111/j.1095-8649.1982.tb03954.x.

Holmes, W.N., and Donaldson, E.M., 1969, The body compartments and the distribution of electrolytes, in Hoar, W.S., and Randall, D.J., eds., Fish physiology: New York, New York, Academic Press, p. 1-89.

Huntingford, F.A., 2004, Implications of domestication and rearing conditions for the behavior of cultivated fishes: Journal of Fish Biology, v. 65, no. s1, p. 122-142, accessed November 12, 2017, at https://doi.org/10.1111/j.00221112.2004.00562.x.

Luna, L.G., 1992, Histopathological methods and color atlas of special stains and tissue: Gaithersburg, Md., American Histolabs, Inc., Publications Division, 258 p.

McDonald, J.H., 2014, Handbook of biological statistics (3d ed.): Baltimore, Md., Sparky House Publishing, 299 p.
Miller, L.C., and Tainter, M.L., 1944, Estimation of $\mathrm{LD}_{50}$ and its error by means of log-probit graph paper: Proceedings of the Society for Experimental Biology and Medicine, v. 57, p. 261.

Moffitt, C.M., Stockton-Fiti, K.A., and Claudi, R., 2016, Toxicity of potassium chloride to veliger and byssal stage dreissenid mussels related to water quality: Management of Biological Invasions, v. 7, no. 3, p. 257-268, accessed March 25, 2017, at http://www.reabic.net/journals/ mbi/2016/3/MBI_2016_Moffitt_etal.pdf.

Nalepa, T.F., 2010, An overview of the spread, distribution, and ecological impacts of the quagga mussel, Dreissena rostriformis bugensis, with possible implications to the Colorado River system: Agencies and Staff of the U.S. Department of Commerce, 412, accessed July 1, 2015, at http://digitalcommons.unl.edu/usdeptcommercepub/412.

National Oceanic and Atmospheric Administration (NOAA) Fisheries, 2016, Chinook salmon (Oncorhynchus tshawytsha): Fisheries Home, Protected Resources, Species, accessed February 23, 2018, at http://www.nmfs.noaa.gov/ $\mathrm{pr} / \mathrm{species} /$ fish/chinook-salmon.html.

Overli, O., Winberg, S., and Pottinger, T.G., 2005, Behavioral and neuroendocrine correlates of selection for stress responsiveness in rainbow trout $-\mathrm{A}$ review: Integrative and Comparative Biology, v. 45, no. 3, p. 463-474, accessed August 11, 2017, at https://doi.org/10.1093/icb/45.3.463.

Perry, S.F., 1998, Relationships between branchial chloride cells and gas transfer in freshwater fish: Comparative Biochemistry and Physiology Part A: Molecular and Integrative Physiology, v. 119, no. 1, p. 9-16, accessed August 11, 2017, at https://doi.org/10.1016/S1095-6433(97)00411-X.

Perry, S.F. and Walsh, P.J., 1989, Metabolism of isolated fish gill cells—Contribution of epithelial chloride cells: Journal of Experimental Biology, v. 144, p. 507-520, accessed August 11, 2017, at http://jeb.biologists.org/content/144/1/507.

Reimschuessel, R., Bennett, R.O., and Lipsky, M.P., 1992, A classification system for histological lesions: Journal of Aquatic Animal Health, v. 4, p. 135-143.

Rydqvist, B., Lin, J.-H., Sand, P., and Swerup, C., 2007, Mechanotransduction and the crayfish stretch receptor: Physiology and Behavior, v. 92, nos. 1-2, p. 21-28, accessed November 12, 2017, at https://doi.org/10.1016/j. physbeh.2007.05.055.

Stickney, R.R., 1994, Use of hatchery fish in enhancement programs: Fisheries, v. 19, no. 5, p. 6-13, accessed August 14, 2017, at http://www.nativefishlab.net/library/textpdf/14332.pdf. 
United Nations Industrial Development Organization-International Fertilizer Development Center (UNIDO-IFDC), 1998, Fertilizer manual: Dordrecht, The Netherlands, Kluwer Academic Publishers, 614 p.

U.S. Environmental Protection Agency (USEPA), 1996a, Ecological effects test guidelines OPPTS 850.1010-Aquatic invertebrate acute toxicity test, freshwater Daphnids: Washington, D.C., U.S. Environmental Protection Agency, Prevention, Pesticides and Toxic Substances (7101), EPA 712-C-96-114, 8 p.

U.S. Environmental Protection Agency (USEPA), 1996b, Ecological effects test guidelines OPPTS 850.1075, Fish acute toxicity test, Freshwater and marine: Washington, D.C., U.S. Environmental Protection Agency, Prevention, Pesticides and Toxic Substances (7101), EPA 712-C-96-118, $11 \mathrm{p}$.

Vijayavel, K., and Balasubramanian, M.P., 2007, Interaction of potash and decis in the ecophysiology of a freshwater fish Oreochromis mossambicus: Ecotoxicology and Environmental Safety, v. 66, no. 2, p. 154-158, accessed August 11, 2017, at https://doi.org/10.1016/j.ecoenv.2005.12.005.

Virginia Department of Game and Inland Fisheries (VDGIF), 2005, Millbrook Quarry zebra mussel and quagga mussel eradication: Final environmental assessment, Virginia, accessed July 1, 2015, at http://www.aquaticnuisance.org/ wordpress/wp-content/uploads/2009/01/Millbrook-QuarryZebra-Mussel-final_zm_-EA-2005.pdf.

Wagner, T., and Congleton, J.L., 2004, Blood chemistry correlates of nutritional condition, tissue damage, and stress in migrating juvenile chinook salmon (Oncorhynchus tshawytscha): Canadian Journal of Fisheries and Aquatic Sciences, v. 61, no. 7, p. 1,066-1,074, accessed August 11, 2017, at https://doi.org/10.1139/f04-050. 

Appendixes 


\section{Appendix 1. Water Chemistry Analysis}

$[\mu \mathrm{S} / \mathrm{cm}$, microsiemens per centimeters; mg/L, milligrams per liter; inorganic analytes (calcium, magnesium, potassium, sodium, and chloride) were measured in experimental water at high $(680 \mu \mathrm{S} / \mathrm{cm})$ and low $(150 \mu \mathrm{S} / \mathrm{cm})$ baseline water conductivity, either supplemented $(800 \mathrm{mg} / \mathrm{L})$ or not supplemented $(0 \mathrm{mg} / \mathrm{L})$ with potassium chloride ( $\mathrm{KCl}$ ); Sample analysis was performed by a commercial water-quality laboratory (Reliance Laboratories Inc., Martinsburg, WV); ND, analyte not detected and presumably below detection limits]

\begin{tabular}{|c|c|c|c|c|c|c|}
\hline \multirow{2}{*}{$\begin{array}{l}\text { Approximate baseline } \\
\text { water conductivity, } \\
\text { in } \mu \mathrm{S} / \mathrm{cm}\end{array}$} & \multirow{2}{*}{$\begin{array}{c}\mathrm{KCl}, \\
\text { in } \mathrm{mg} / \mathrm{L}\end{array}$} & \multicolumn{5}{|c|}{ Analyte concentration, in mg/L } \\
\hline & & Calcium & Magnesium & Potassium & Sodium & Chloride \\
\hline 680 & 0 & 84.1 & 10.8 & 1.65 & 4.43 & 8.4 \\
\hline 150 & 0 & 30.1 & 1.89 & ND & 0.64 & 1.85 \\
\hline 680 & 800 & 80.2 & 9.18 & 552 & 3.85 & 393 \\
\hline 150 & 800 & 28.7 & 1.64 & 450 & 1.09 & 379 \\
\hline
\end{tabular}




\section{Appendix 2. Ionized potassium measurements-96-hour acute toxicity tests.}

[KCl, potassium chloride; $\mathrm{mg} / \mathrm{L}$, milligrams per liter; $\mathrm{K}^{+}$, ionized potassium; DI, deionized; Ionized potassium values from test water used in the four acute toxicity tests (high and low baseline water conductivity with brook trout and Chinook salmon) are provided in this table. Potassium anion concentration in test water was measured at the onset of each trial with a portable meter (Horiba LAQUAtwin potassium $\mathrm{K}^{+}$compaction meter, Horiba Scientific Ltd., Kyoto, Japan)]

\begin{tabular}{|c|c|c|c|}
\hline Species & $\begin{array}{c}\text { Baseline water } \\
\text { conductivity level }\end{array}$ & $\begin{array}{c}\mathrm{KCl}, \\
\text { in } \mathrm{mg} / \mathrm{L}\end{array}$ & $\begin{array}{l}\text { Measured } \mathrm{K}^{+} \text {, } \\
\text { in } \mathrm{mg} / \mathrm{L}\end{array}$ \\
\hline \multirow{16}{*}{ Brook trout } & \multirow{8}{*}{ High } & DI water & 0 \\
\hline & & 0 & 1 \\
\hline & & 25 & 11 \\
\hline & & 50 & 24 \\
\hline & & 100 & 44 \\
\hline & & 200 & 100 \\
\hline & & 400 & 190 \\
\hline & & 800 & 360 \\
\hline & \multirow{8}{*}{ Low } & DI water & 0 \\
\hline & & 0 & 1 \\
\hline & & 25 & 11 \\
\hline & & 50 & 23 \\
\hline & & 100 & 45 \\
\hline & & 200 & 96 \\
\hline & & 400 & 190 \\
\hline & & 800 & 380 \\
\hline \multirow{16}{*}{ Chinook salmon } & \multirow{8}{*}{ High } & DI water & 0 \\
\hline & & 0 & 1 \\
\hline & & 25 & 12 \\
\hline & & 50 & 23 \\
\hline & & 100 & 44 \\
\hline & & 200 & 91 \\
\hline & & 400 & 190 \\
\hline & & 800 & 390 \\
\hline & \multirow{8}{*}{ Low } & DI water & 0 \\
\hline & & 0 & 1 \\
\hline & & 25 & 11 \\
\hline & & 50 & 22 \\
\hline & & 100 & 47 \\
\hline & & 200 & 96 \\
\hline & & 400 & 200 \\
\hline & & 800 & 370 \\
\hline
\end{tabular}


Appendix 3A. Water-quality measurements (temperature, $\mathrm{pH}$, conductivity, and dissolved oxygen) collected daily from all experimental tanks for the 96-hour potassium chloride (KCI) toxicity test, with brook trout at high baseline water conductivity.

[mg/L, milligrams per liter; ${ }^{\circ} \mathrm{C}$, degrees Celsius; $\mu \mathrm{S} / \mathrm{cm}$, microsiemens per centimeter; —, not applicable]

\begin{tabular}{|c|c|c|c|c|c|}
\hline $\mathrm{KCl}$ added, in mg/L & Replicate & $\begin{array}{l}\text { Water temperature, } \\
\text { in }{ }^{\circ} \mathrm{C}\end{array}$ & Water pH & $\begin{array}{c}\text { Water conductivity, } \\
\text { in } \mu \mathrm{S} / \mathrm{cm}\end{array}$ & $\begin{array}{c}\text { Dissolved oxygen, } \\
\text { in } \mathrm{mg} / \mathrm{L}\end{array}$ \\
\hline \multicolumn{6}{|c|}{ Day 1} \\
\hline 0 & $\mathrm{a}$ & 13.1 & 8.4 & 526 & 11.3 \\
\hline 0 & $\mathrm{c}$ & 12.7 & 8.4 & 465 & 11 \\
\hline 25 & $\mathrm{a}$ & 12.9 & 8.2 & 596 & 10.2 \\
\hline 25 & $\mathrm{~b}$ & 12.8 & 8.4 & 491 & 11.1 \\
\hline 50 & $\mathrm{a}$ & 12.9 & 8.2 & 694 & 9.5 \\
\hline 50 & $\mathrm{~b}$ & 12.9 & 8.2 & 676 & 9.2 \\
\hline 50 & $\mathrm{c}$ & 12.9 & 8.5 & 576 & 10.9 \\
\hline 100 & $\mathrm{a}$ & 12.8 & 8.5 & 668 & 11 \\
\hline 100 & $\mathrm{~b}$ & 12.8 & 8.3 & 760 & 10.3 \\
\hline 100 & $\mathrm{c}$ & 12.8 & 8.3 & 701 & 10.2 \\
\hline 400 & $\mathrm{~b}$ & 12.9 & 8.2 & 1,398 & 10.2 \\
\hline 400 & $\mathrm{c}$ & 12.8 & 8.2 & 1,347 & 10.3 \\
\hline 800 & $\mathrm{a}$ & 12.9 & 8.2 & 2,120 & 10 \\
\hline 800 & $\mathrm{~b}$ & 12.8 & 8.4 & 1,992 & 11 \\
\hline 800 & $\mathrm{c}$ & 12.8 & 8.4 & 2,180 & 10.9 \\
\hline Spare & - & 13 & 8.5 & 472 & 12.3 \\
\hline \multicolumn{6}{|c|}{ Day 2} \\
\hline 0 & $\mathrm{a}$ & 13 & 8.5 & 476 & 10.6 \\
\hline 0 & b & 12.9 & 8.3 & 433 & 11.2 \\
\hline 0 & $\mathrm{c}$ & 12.8 & 8.4 & 423 & 10.7 \\
\hline 25 & $\mathrm{a}$ & 12.9 & 8.3 & 565 & 10.6 \\
\hline 100 & $\mathrm{c}$ & 12.8 & 8.3 & 687 & 10.6 \\
\hline 200 & $\mathrm{a}$ & 12.9 & 8.5 & 888 & 11.3 \\
\hline 200 & b & 12.9 & 8.5 & 840 & 11.2 \\
\hline 200 & $\mathrm{c}$ & 12.8 & 8.3 & 877 & 10.9 \\
\hline 400 & $\mathrm{a}$ & 12.9 & 8.3 & 1,322 & 10.3 \\
\hline 400 & $\mathrm{~b}$ & 12.9 & 8.3 & 1,370 & 10.1 \\
\hline 400 & $\mathrm{c}$ & 12.8 & 8.3 & 1,377 & 10.5 \\
\hline 800 & $\mathrm{a}$ & 12.9 & 8.3 & 1,998 & 10.4 \\
\hline 800 & $\mathrm{~b}$ & 12.8 & 8.4 & 1,974 & 10.9 \\
\hline 800 & $\mathrm{c}$ & 12.8 & 8.4 & 2,150 & 10.8 \\
\hline Spare & - & 13 & 8.6 & 398 & 12 \\
\hline
\end{tabular}




\begin{tabular}{|c|c|c|c|c|c|}
\hline $\mathrm{KCl}$ added, in mg/L & Replicate & $\begin{array}{l}\text { Water temperature, } \\
\text { in }{ }^{\circ} \mathrm{C}\end{array}$ & Water pH & $\begin{array}{l}\text { Water conductivity, } \\
\text { in } \mu \mathrm{S} / \mathrm{cm}\end{array}$ & $\begin{array}{l}\text { Dissolved oxygen, } \\
\text { in } \mathrm{mg} / \mathrm{L}\end{array}$ \\
\hline \multicolumn{6}{|c|}{ Day 3} \\
\hline 0 & $\mathrm{a}$ & 12.9 & 8.4 & 590 & 11.1 \\
\hline 0 & $\mathrm{~b}$ & 12.8 & 8.5 & 553 & 11.5 \\
\hline 0 & $\mathrm{c}$ & 12.8 & 8.5 & 562 & 11.3 \\
\hline 25 & $\mathrm{a}$ & 12.8 & 8.3 & 673 & 10.6 \\
\hline 25 & $\mathrm{~b}$ & 12.8 & 8.5 & 593 & 11.5 \\
\hline 25 & $\mathrm{c}$ & 12.8 & 8.4 & 606 & 11.3 \\
\hline 50 & $\mathrm{a}$ & 12.8 & 8.4 & 707 & 10.9 \\
\hline 50 & $\mathrm{~b}$ & 12.8 & 8.4 & 701 & 10.9 \\
\hline 50 & $\mathrm{c}$ & 12.8 & 8.5 & 664 & 11.3 \\
\hline 100 & $\mathrm{a}$ & 12.8 & 8.5 & 756 & 11.3 \\
\hline 100 & b & 12.8 & 8.3 & 833 & 10.6 \\
\hline 100 & $\mathrm{c}$ & 12.8 & 8.3 & 833 & 10.6 \\
\hline 200 & $\mathrm{a}$ & 12.9 & 8.5 & 985 & 11.7 \\
\hline 200 & b & 12.9 & 8.5 & 967 & 11.4 \\
\hline 200 & $\mathrm{c}$ & 12.8 & 8.3 & 1,015 & 11.1 \\
\hline 400 & $\mathrm{a}$ & 12.8 & 8.3 & 1,458 & 10.9 \\
\hline 400 & b & 12.8 & 8.3 & 1,433 & 10.6 \\
\hline 400 & $\mathrm{c}$ & 12.8 & 8.4 & 1,414 & 11.1 \\
\hline 800 & $\mathrm{a}$ & 12.9 & 8.3 & 2,250 & 10.5 \\
\hline 800 & $\mathrm{~b}$ & 12.8 & 8.5 & 2,180 & 11.2 \\
\hline 800 & $\mathrm{c}$ & 12.8 & 8.4 & 2,120 & 11.3 \\
\hline Spare & - & 13 & 8.5 & 366 & 12.2 \\
\hline \multicolumn{6}{|c|}{ Day 4} \\
\hline 0 & $\mathrm{a}$ & 12.8 & 8.4 & 512 & 11.2 \\
\hline 0 & b & 12.8 & 8.5 & 464 & 11.6 \\
\hline 0 & $\mathrm{c}$ & 12.7 & 8.4 & 475 & 11.4 \\
\hline 25 & $\mathrm{a}$ & 12.8 & 8.3 & 623 & 10.6 \\
\hline 25 & $\mathrm{~b}$ & 12.7 & 8.4 & 499 & 11.6 \\
\hline 25 & $\mathrm{c}$ & 12.8 & 8.5 & 518 & 11.5 \\
\hline 50 & $\mathrm{a}$ & 12.8 & 8.4 & 643 & 11.1 \\
\hline 50 & $\mathrm{~b}$ & 12.8 & 8.4 & 634 & 11.2 \\
\hline 50 & $\mathrm{c}$ & 12.7 & 8.5 & 585 & 11.4 \\
\hline 100 & $\mathrm{a}$ & 12.7 & 8.4 & 676 & 11.4 \\
\hline 100 & b & 12.7 & 8.3 & 780 & 10.8 \\
\hline 100 & $\mathrm{c}$ & 12.7 & 8.3 & 778 & 10.9 \\
\hline 200 & $\mathrm{a}$ & 12.8 & 8.5 & 918 & 11.6 \\
\hline 200 & b & 12.8 & 8.5 & 883 & 11.5 \\
\hline 200 & $\mathrm{c}$ & 12.7 & 8.4 & 957 & 11.2 \\
\hline 400 & $\mathrm{a}$ & 12.8 & 8.3 & 1,407 & 10.8 \\
\hline 400 & $\mathrm{~b}$ & 12.8 & 8.3 & 1,391 & 10.6 \\
\hline 400 & $\mathrm{c}$ & 12.7 & 8.4 & 1,369 & 11.3 \\
\hline 800 & $\mathrm{a}$ & 12.8 & 8.3 & 2,220 & 10.6 \\
\hline 800 & b & 12.7 & 8.4 & 2,120 & 11.5 \\
\hline 800 & $\mathrm{c}$ & 12.8 & 8.5 & 1,977 & 11.4 \\
\hline Spare & - & 12.8 & 8.6 & 354 & 11.8 \\
\hline
\end{tabular}


Appendix 3B. Water-quality measurements (temperature, pH, conductivity, and dissolved oxygen) collected daily from all experimental tanks for the 96-hour potassium chloride (KCI) toxicity test with brook trout at low baseline water conductivity.

$\left[\mathrm{mg} / \mathrm{L}\right.$, milligrams per liter; ${ }^{\circ} \mathrm{C}$, degrees Celsius; $\mu \mathrm{S} / \mathrm{cm}$, microsiemens per centimete; —, not applicable]

\begin{tabular}{|c|c|c|c|c|c|}
\hline $\mathrm{KCl}$ added, in mg/L & Replicate & $\begin{array}{l}\text { Water temperature, } \\
\text { in }{ }^{\circ} \mathrm{C}\end{array}$ & Water pH & $\begin{array}{l}\text { Water conductivity, } \\
\text { in } \mu \mathrm{S} / \mathrm{cm}\end{array}$ & $\begin{array}{c}\text { Dissolved oxygen, } \\
\text { in } \mathrm{mg} / \mathrm{L}\end{array}$ \\
\hline \multicolumn{6}{|c|}{ Day 1} \\
\hline 0 & $\mathrm{a}$ & 13.2 & 8 & 166 & 10.5 \\
\hline 0 & $\mathrm{~b}$ & 13 & 7.9 & 168 & 10.4 \\
\hline 0 & $\mathrm{c}$ & 12.8 & 8 & 166 & 11.6 \\
\hline 25 & $\mathrm{a}$ & 13 & 8 & 205 & 10.6 \\
\hline 25 & $\mathrm{~b}$ & 12.9 & 7.8 & 217 & 10.9 \\
\hline 25 & $\mathrm{c}$ & 13 & 7.7 & 205 & 9.8 \\
\hline 50 & a & 12.9 & 7.8 & 269 & 10.1 \\
\hline 50 & b & 12.9 & 7.9 & 259 & 10.7 \\
\hline 50 & $\mathrm{c}$ & 12.9 & 7.8 & 260 & 10.2 \\
\hline 100 & $\mathrm{a}$ & 12.9 & 7.8 & 361 & 10.9 \\
\hline 100 & $\mathrm{~b}$ & 13 & 7.7 & 380 & 10.3 \\
\hline 100 & $\mathrm{c}$ & 12.9 & 7.8 & 368 & 10.5 \\
\hline 200 & $\mathrm{a}$ & 13.1 & 8 & 588 & 11.2 \\
\hline 200 & $\mathrm{~b}$ & 13.1 & 8 & 573 & 11 \\
\hline 200 & $\mathrm{c}$ & 12.8 & 7.9 & 566 & 10.8 \\
\hline 400 & $\mathrm{a}$ & 13 & 7.6 & 959 & 8.3 \\
\hline 400 & b & 13 & 7.6 & 985 & 9.8 \\
\hline 400 & $\mathrm{c}$ & 12.9 & 7.9 & 953 & 10.8 \\
\hline 800 & $\mathrm{a}$ & 13 & 7.5 & 1,740 & 10.5 \\
\hline 800 & $\mathrm{~b}$ & 13 & 8 & 1,672 & 11.5 \\
\hline 800 & $\mathrm{c}$ & 13 & 7.6 & 1,624 & 10.7 \\
\hline Spare & - & 13.1 & 8.4 & 159 & 11.5 \\
\hline \multicolumn{6}{|c|}{ Day 2} \\
\hline 0 & $\mathrm{a}$ & 13.1 & 8 & 177 & 10.7 \\
\hline 0 & $\mathrm{~b}$ & 12.8 & 7.8 & 176 & 10.7 \\
\hline 0 & $\mathrm{c}$ & 12.7 & 8 & 171 & 11.4 \\
\hline 25 & $\mathrm{a}$ & 12.9 & 8 & 216 & 10.9 \\
\hline 25 & $\mathrm{~b}$ & 12.8 & 7.9 & 215 & 10.9 \\
\hline 25 & $\mathrm{c}$ & 12.8 & 7.6 & 217 & 10.2 \\
\hline 50 & a & 12.9 & 8 & 276 & 10.6 \\
\hline 50 & $\mathrm{~b}$ & 12.9 & 7.7 & 271 & 10.9 \\
\hline 50 & $\mathrm{c}$ & 12.8 & 7.7 & 278 & 10.4 \\
\hline 100 & a & 12.9 & 7.8 & 373 & 10.9 \\
\hline 100 & b & 12.8 & 7.6 & 394 & 10.4 \\
\hline 100 & $\mathrm{c}$ & 12.8 & 7.7 & 381 & 10.7 \\
\hline 200 & $\mathrm{a}$ & 12.9 & 8 & 597 & 11.2 \\
\hline 200 & $\mathrm{~b}$ & 12.9 & 7.7 & 587 & 11.1 \\
\hline 200 & $\mathrm{c}$ & 12.9 & 7.8 & 581 & 10.9 \\
\hline 400 & $\mathrm{a}$ & 12.9 & 7.8 & 976 & 10.6 \\
\hline 400 & $\mathrm{~b}$ & 12.9 & 7.7 & 1002 & 10.8 \\
\hline 400 & $\mathrm{c}$ & 12.8 & 7.8 & 969 & 10.9 \\
\hline 800 & $\mathrm{a}$ & 12.9 & 7.7 & 1,788 & 10.6 \\
\hline 800 & $\mathrm{~b}$ & 12.9 & 7.9 & 1,702 & 11.3 \\
\hline 800 & $\mathrm{c}$ & 12.9 & 7.7 & 1,682 & 10.9 \\
\hline Spare & - & 13 & 8.4 & 162 & 11.5 \\
\hline
\end{tabular}




\begin{tabular}{|c|c|c|c|c|c|}
\hline $\mathrm{KCl}$ added, in mg/L & Replicate & $\begin{array}{l}\text { Water temperature, } \\
\text { in }{ }^{\circ} \mathrm{C}\end{array}$ & Water pH & $\begin{array}{l}\text { Water conductivity, } \\
\text { in } \mu \mathrm{S} / \mathrm{cm}\end{array}$ & $\begin{array}{l}\text { Dissolved oxygen, } \\
\text { in } \mathrm{mg} / \mathrm{L}\end{array}$ \\
\hline \multicolumn{6}{|c|}{ Day 3} \\
\hline 0 & $\mathrm{a}$ & 13 & 7.9 & 160 & 11.7 \\
\hline 0 & $\mathrm{~b}$ & 12.8 & 7.9 & 163 & 11.1 \\
\hline 0 & $\mathrm{c}$ & 12.8 & 8.1 & 158 & 11.3 \\
\hline 25 & $\mathrm{a}$ & 12.9 & 7.9 & 205 & 11.3 \\
\hline 25 & $\mathrm{~b}$ & 12.8 & 7.8 & 200 & 11.2 \\
\hline 25 & $\mathrm{c}$ & 12.8 & 7.8 & 205 & 10.8 \\
\hline 50 & a & 12.8 & 7.8 & 260 & 11.3 \\
\hline 50 & $\mathrm{~b}$ & 12.8 & 7.9 & 259 & 10.9 \\
\hline 50 & $\mathrm{c}$ & 12.8 & 7.9 & 263 & 11.1 \\
\hline 100 & $\mathrm{a}$ & 12.8 & 7.9 & 374 & 11 \\
\hline 100 & $\mathrm{~b}$ & 12.8 & 7.7 & 369 & 10.7 \\
\hline 100 & $\mathrm{c}$ & 12.8 & 7.7 & 369 & 10.6 \\
\hline 200 & $\mathrm{a}$ & 12.9 & 7.9 & 598 & 11.8 \\
\hline 200 & $\mathrm{~b}$ & 12.9 & 8 & 584 & 11.3 \\
\hline 200 & $\mathrm{c}$ & 12.8 & 8 & 575 & 11.3 \\
\hline 400 & $\mathrm{a}$ & 12.8 & 7.7 & 1,065 & 11.1 \\
\hline 400 & $\mathrm{~b}$ & 12.8 & 7.8 & 999 & 10.9 \\
\hline 400 & $\mathrm{c}$ & 12.8 & 7.8 & 1,084 & 11 \\
\hline 800 & $\mathrm{a}$ & 12.9 & 7.8 & 1,659 & 10.9 \\
\hline 800 & $\mathrm{~b}$ & 12.8 & 7.9 & 1801 & 11.4 \\
\hline 800 & $\mathrm{c}$ & 12.9 & 7.7 & 1808 & 10.8 \\
\hline Spare & - & 13 & 8.3 & 155 & 12.7 \\
\hline \multicolumn{6}{|c|}{ Day 4} \\
\hline 0 & $\mathrm{a}$ & 13 & 8 & 169 & 11.3 \\
\hline 0 & $\mathrm{~b}$ & 12.8 & 7.9 & 171 & 10.9 \\
\hline 0 & $\mathrm{c}$ & 12.8 & 8.1 & 166 & 11.3 \\
\hline 25 & $\mathrm{a}$ & 12.9 & 7.9 & 208 & 11.2 \\
\hline 25 & $\mathrm{~b}$ & 12.8 & 8 & 209 & 11.2 \\
\hline 25 & $\mathrm{c}$ & 12.8 & 7.8 & 212 & 10.8 \\
\hline 50 & $\mathrm{a}$ & 12.8 & 7.8 & 268 & 11.1 \\
\hline 50 & $\mathrm{~b}$ & 12.7 & 7.9 & 270 & 10.9 \\
\hline 50 & $\mathrm{c}$ & 12.8 & 8.0 & 270 & 11.1 \\
\hline 100 & $\mathrm{a}$ & 12.8 & 7.9 & 382 & 11.1 \\
\hline 100 & $\mathrm{~b}$ & 12.8 & 7.8 & 381 & 10.7 \\
\hline 100 & c & 12.8 & 7.8 & 378 & 10.6 \\
\hline 200 & $\mathrm{a}$ & 12.8 & 7.9 & 605 & 11.5 \\
\hline 200 & $\mathrm{~b}$ & 12.9 & 8 & 592 & 11.2 \\
\hline 200 & $\mathrm{c}$ & 12.8 & 8 & 586 & 11.3 \\
\hline 400 & $\mathrm{a}$ & 12.8 & 7.8 & 1,076 & 11.1 \\
\hline 400 & $\mathrm{~b}$ & 12.8 & 7.7 & 1,005 & 11 \\
\hline 400 & $\mathrm{c}$ & 12.8 & 7.8 & 1,094 & 11 \\
\hline 800 & $\mathrm{a}$ & 12.8 & 7.8 & 1,675 & 11 \\
\hline 800 & $\mathrm{~b}$ & 12.8 & 8 & 1,812 & 11.4 \\
\hline 800 & $\mathrm{c}$ & 12.9 & 7.8 & 1,818 & 10.7 \\
\hline Spare & - & 13 & 8.3 & 157 & 12.2 \\
\hline
\end{tabular}


Appendix 3C. Water-quality measurements (temperature, pH, conductivity, and dissolved oxygen) collected daily from all experimental tanks for the 96-hour potassium chloride ( $\mathrm{KCl}$ ) toxicity test with Chinook salmon at high baseline water conductivity.

[mg/L, milligrams per liter; ${ }^{\circ} \mathrm{C}$, degrees Celsius; $\mu \mathrm{S} / \mathrm{cm}$, microsiemens per centimeter; —, not applicable]

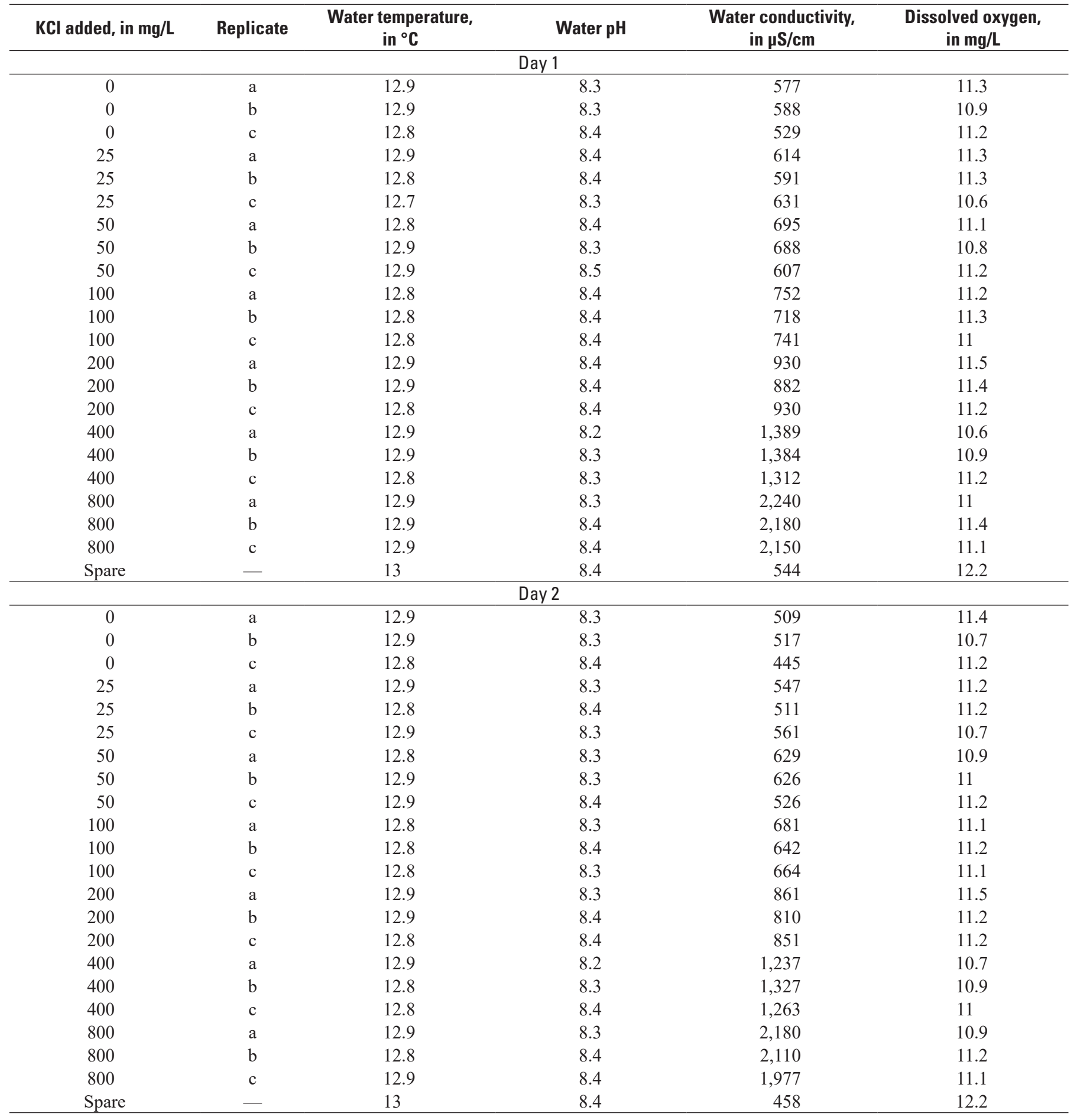




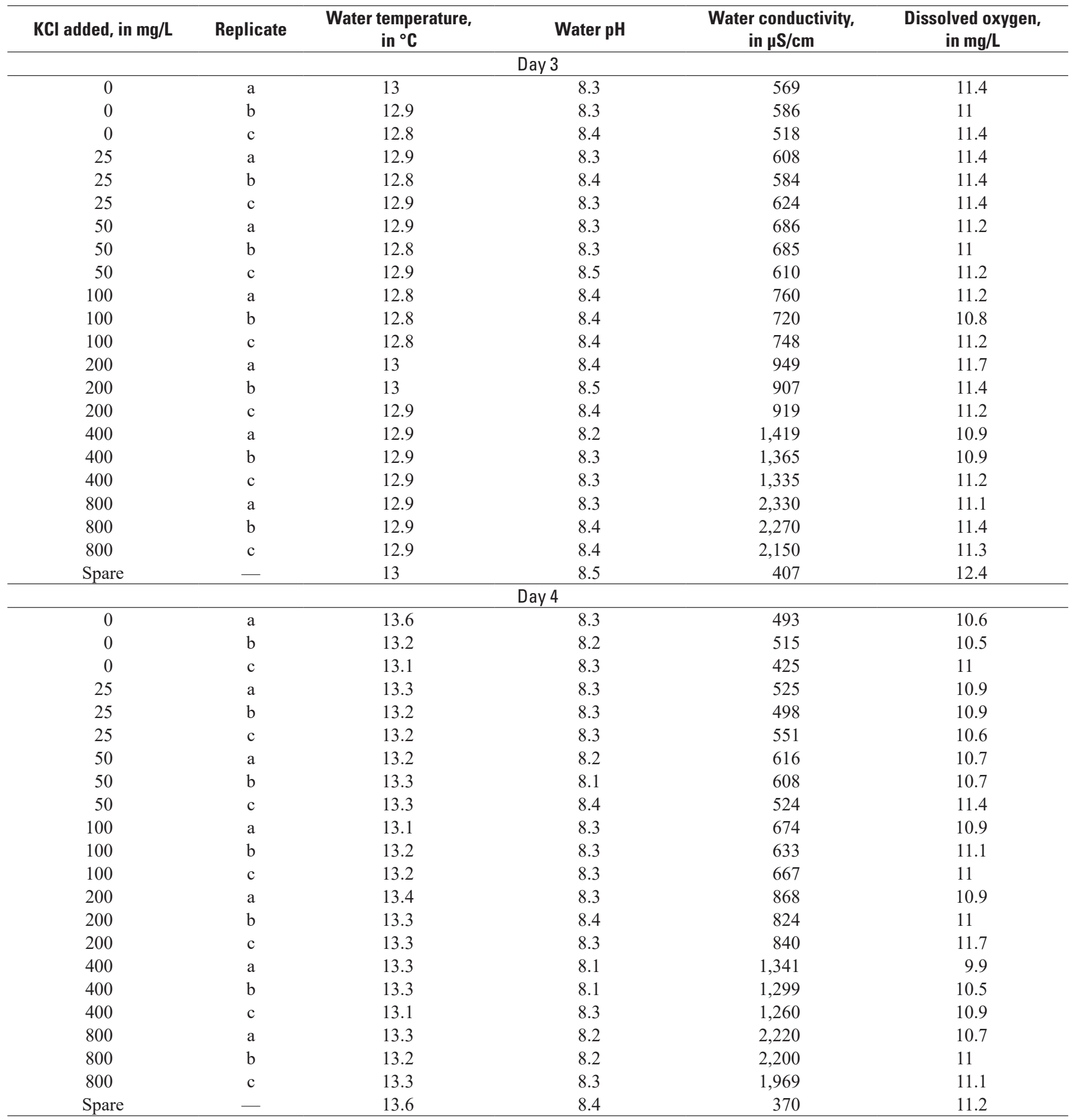


Appendix 3D. Water-quality measurements (temperature, $\mathrm{pH}$, conductivity, and dissolved oxygen) collected daily from all experimental tanks for the 96-hour potassium chloride (KCI) toxicity test with Chinook salmon at low baseline water conductivity.

[mg/L, milligrams per liter; ${ }^{\circ} \mathrm{C}$, degrees Celsius; $\mu \mathrm{S} / \mathrm{cm}$, microsiemens per centimeter; —, not applicable]

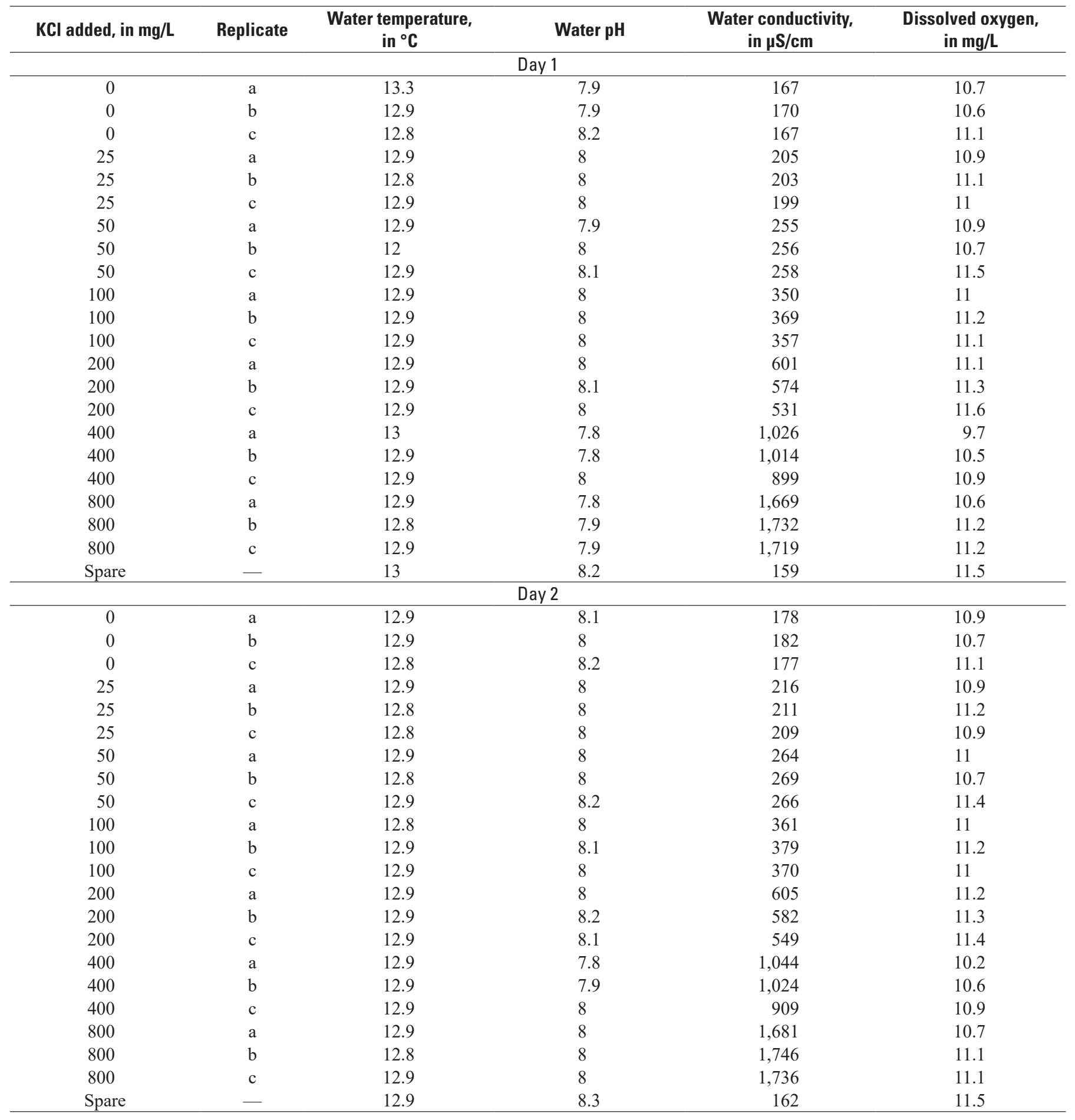




\begin{tabular}{|c|c|c|c|c|c|}
\hline $\mathrm{KCl}$ added, in mg/L & Replicate & $\begin{array}{l}\text { Water temperature, } \\
\text { in }{ }^{\circ} \mathrm{C}\end{array}$ & Water pH & $\begin{array}{l}\text { Water conductivity, } \\
\text { in } \mu \mathrm{S} / \mathrm{cm}\end{array}$ & $\begin{array}{l}\text { Dissolved oxygen, } \\
\text { in } \mathrm{mg} / \mathrm{L}\end{array}$ \\
\hline \multicolumn{6}{|c|}{ Day 3} \\
\hline 0 & $\mathrm{a}$ & 13.2 & 8 & 157 & 10.8 \\
\hline 0 & $\mathrm{~b}$ & 13.3 & 8 & 163 & 10.8 \\
\hline 0 & $\mathrm{c}$ & 13.1 & 8.2 & 160 & 11.3 \\
\hline 25 & $\mathrm{a}$ & 13.3 & 8 & 195 & 10.9 \\
\hline 25 & $\mathrm{~b}$ & 13.1 & 8.1 & 197 & 11.2 \\
\hline 25 & $\mathrm{c}$ & 13.1 & 8 & 194 & 11.1 \\
\hline 50 & $\mathrm{a}$ & 13.2 & 7.9 & 248 & 11 \\
\hline 50 & $\mathrm{~b}$ & 13.1 & 8 & 251 & 10.8 \\
\hline 50 & $\mathrm{c}$ & 13 & 8.1 & 243 & 11.6 \\
\hline 100 & $\mathrm{a}$ & 13.2 & 8 & 356 & 11.1 \\
\hline 100 & $\mathrm{~b}$ & 12.9 & 8 & 353 & 11.3 \\
\hline 100 & $\mathrm{c}$ & 13 & 8 & 361 & 11.2 \\
\hline 200 & $\mathrm{a}$ & 13 & 7.9 & 547 & 11.1 \\
\hline 200 & $\mathrm{~b}$ & 13.1 & 8.1 & 536 & 11.4 \\
\hline 200 & $\mathrm{c}$ & 13 & 8 & 544 & 11.8 \\
\hline 400 & $\mathrm{a}$ & 13.3 & 7.8 & 1,020 & 10.1 \\
\hline 400 & $\mathrm{~b}$ & 13.3 & 7.8 & 996 & 10.6 \\
\hline 400 & c & 13.1 & 7.9 & 898 & 11 \\
\hline 800 & $\mathrm{a}$ & 13.3 & 7.9 & 1,677 & 10.9 \\
\hline 800 & $\mathrm{~b}$ & 13.2 & 7.9 & 1,747 & 11.3 \\
\hline 800 & $\mathrm{c}$ & 13.1 & 7.9 & 1,630 & 11.4 \\
\hline Spare & - & 13 & 8.2 & 167 & 11.5 \\
\hline \multicolumn{6}{|c|}{ Day 4} \\
\hline 0 & $\mathrm{a}$ & 13.1 & 8.1 & 175 & 11 \\
\hline 0 & $\mathrm{~b}$ & 13 & 8.1 & 176 & 10.9 \\
\hline 0 & $\mathrm{c}$ & 12.9 & 8.1 & 170 & 11.4 \\
\hline 25 & $\mathrm{a}$ & 13 & 8 & 207 & 11.1 \\
\hline 25 & $\mathrm{~b}$ & 13 & 8.1 & 200 & 11.4 \\
\hline 25 & $\mathrm{c}$ & 13 & 8 & 206 & 11.2 \\
\hline 50 & $\mathrm{a}$ & 13 & 8 & 257 & 11.2 \\
\hline 50 & $\mathrm{~b}$ & 13.1 & 8 & 262 & 11 \\
\hline 50 & $\mathrm{c}$ & 13 & 8.1 & 251 & 11.7 \\
\hline 100 & a & 13 & 8 & 365 & 11.3 \\
\hline 100 & $\mathrm{~b}$ & 13 & 8 & 364 & 11.5 \\
\hline 100 & $\mathrm{c}$ & 13 & 8 & 375 & 11.3 \\
\hline 200 & $\mathrm{a}$ & 13.1 & 8 & 575 & 11.4 \\
\hline 200 & $\mathrm{~b}$ & 13 & 8.1 & 546 & 11.5 \\
\hline 200 & $\mathrm{c}$ & 13 & 8 & 571 & 11.8 \\
\hline 400 & $\mathrm{a}$ & 13.1 & 7.9 & 1,048 & 10.4 \\
\hline 400 & $\mathrm{~b}$ & 13 & 7.8 & 1,019 & 10.8 \\
\hline 400 & $\mathrm{c}$ & 13 & 8 & 1,002 & 11.2 \\
\hline 800 & $\mathrm{a}$ & 13.1 & 8 & 1,689 & 11 \\
\hline 800 & $\mathrm{~b}$ & 13 & 7.9 & 1,789 & 11.4 \\
\hline 800 & $\mathrm{c}$ & 13 & 8 & 1,660 & 11.6 \\
\hline Spare & - & 13.1 & 8.2 & 176 & 11.6 \\
\hline
\end{tabular}




\section{Appendix 3E. Water-quality parameters for a 24-hour potassium chloride (KCI) exposure evaluating physiological impacts on brook trout at high baseline water conductivity (680 microsiemens per centimeter).}

[ID, identifier; ${ }^{\circ} \mathrm{C}$, degrees Celsius; $\mathrm{mg} / \mathrm{L}$, milligrams per liter; $\mu \mathrm{S} / \mathrm{cm}$, microsiemens per centimeter; ND, no data available; note that the time $=0$ conductivity reading is measured before the addition of $\mathrm{KCl}$ to the experimental tank whereas the ionized potassium $\left(\mathrm{K}^{+}\right)$measurement is taken following the potassium chloride $(\mathrm{KCl})$ addition]

\begin{tabular}{|c|c|c|c|c|c|c|c|c|c|c|}
\hline \multicolumn{6}{|c|}{ Time $=0$ (Start) } & \multicolumn{5}{|c|}{ Time=24 hours (Terminus) } \\
\hline $\begin{array}{c}\text { Tank } \\
\text { ID }\end{array}$ & $\begin{array}{c}\text { Water } \\
\text { temperature, } \\
\text { in }{ }^{\circ} \mathrm{C}\end{array}$ & $\begin{array}{c}\text { Water } \\
\text { conductivity, } \\
\text { in } \mu S / \mathrm{cm}\end{array}$ & $\begin{array}{c}\text { Water } \\
\text { pH }\end{array}$ & $\begin{array}{l}\text { Dissolved } \\
\text { oxygen, } \\
\text { in } \mathrm{mg} / \mathrm{L}\end{array}$ & $\begin{array}{c}\mathrm{K}^{+}, \\
\text {in } \mathrm{mg} / \mathrm{L}\end{array}$ & $\begin{array}{c}\text { Tank } \\
\text { ID }\end{array}$ & $\begin{array}{c}\text { Water } \\
\text { temperature, } \\
\text { in }{ }^{\circ} \mathrm{C}\end{array}$ & $\begin{array}{c}\text { Water } \\
\text { conductivity, } \\
\text { in } \mu S / \mathrm{cm}\end{array}$ & $\begin{array}{c}\text { Water } \\
\text { pH }\end{array}$ & $\begin{array}{c}\text { Dissolved } \\
\text { oxygen, } \\
\text { in } \mathrm{mg} / \mathrm{L}\end{array}$ \\
\hline $0-\mathrm{A}$ & 13.4 & 577 & 8.6 & 10.6 & 1 & $0-\mathrm{A}$ & 13.5 & 481 & 8.5 & 10.6 \\
\hline $0-\mathrm{B}$ & 13.5 & 574 & 8.6 & 10.3 & 1 & $0-B$ & 13.5 & 476 & 8.5 & 11 \\
\hline $0-\mathrm{C}$ & 13.4 & 495 & 8.5 & 10.4 & 1 & $0-\mathrm{C}$ & 13.5 & 415 & 8.4 & 9.9 \\
\hline $0-\mathrm{D}$ & 13.4 & 571 & 8.7 & 10.4 & 2 & $0-\mathrm{D}$ & 13.5 & 482 & 8.5 & 10.4 \\
\hline $0-\mathrm{E}$ & 13.5 & 574 & 8.4 & 9.8 & 1 & $0-\mathrm{E}$ & 13.6 & 491 & 8.4 & 9.5 \\
\hline $0-\mathrm{F}$ & 13.5 & 491 & 8.6 & 10.4 & 1 & $0-\mathrm{F}$ & 13.6 & 411 & 8.4 & 10.5 \\
\hline $0-\mathrm{G}$ & 13.5 & 569 & 8.5 & 9.7 & 1 & $0-\mathrm{G}$ & 13.6 & 492 & 8.4 & 9.6 \\
\hline $0-\mathrm{H}$ & 13.6 & 503 & 8.4 & 13.6 & ND & $0-\mathrm{H}$ & 13.5 & 455 & 8.5 & 10.9 \\
\hline $0-\mathrm{I}$ & 13.5 & 541 & 8.5 & 11.2 & ND & $0-\mathrm{I}$ & 13.6 & 510 & 8.5 & 11.6 \\
\hline $0-\mathrm{J}$ & 13.5 & 584 & 8.4 & 10.2 & ND & $0-\mathrm{J}$ & 13.6 & 559 & 8.5 & 10.3 \\
\hline $0-\mathrm{K}$ & 13.5 & 597 & 8.4 & 10.2 & ND & $0-\mathrm{K}$ & 13.6 & 560 & 8.4 & 9.9 \\
\hline $0-\mathrm{L}$ & 13.6 & 558 & 8.4 & 9.7 & ND & $0-\mathrm{L}$ & 13.7 & 534 & 8.3 & 9.6 \\
\hline $0-\mathrm{M}$ & 13.6 & 561 & 8.5 & 10.2 & ND & $0-\mathrm{M}$ & 13.7 & 544 & 8.4 & 9.9 \\
\hline $0-\mathrm{N}$ & 13.6 & 596 & 8.4 & 9.4 & ND & $0-\mathrm{N}$ & 13.7 & 568 & 8.4 & 9.4 \\
\hline $200-A$ & 13.5 & 636 & 8.7 & 9.9 & 80 & $200-\mathrm{A}$ & 13.6 & 892 & 8.6 & 10.1 \\
\hline 200-B & 13.5 & 610 & 8.6 & 10.1 & 75 & $200-B$ & 13.6 & 852 & 8.5 & 9.6 \\
\hline $200-\mathrm{C}$ & 13.5 & 561 & 8.6 & 10.3 & 81 & $200-\mathrm{C}$ & 13.6 & 820 & 8.5 & 9.7 \\
\hline 200-D & 13.4 & 404 & 8.5 & 10.4 & 77 & $200-\mathrm{D}$ & 13.6 & 720 & 8.4 & 9.8 \\
\hline $200-E$ & 13.4 & 460 & 8.5 & 10.4 & 78 & $200-E$ & 13.6 & 780 & 8.5 & 10.2 \\
\hline $200-\mathrm{F}$ & 13.5 & 410 & 8.4 & 10.2 & 77 & $200-\mathrm{F}$ & 13.5 & 749 & 8.5 & 10.2 \\
\hline $200-\mathrm{G}$ & 13.4 & 531 & 8.5 & 10.2 & 80 & $200-\mathrm{G}$ & 13.4 & 885 & 8.6 & 9.6 \\
\hline $200-\mathrm{H}$ & 13.6 & 522 & 8.6 & 10.4 & ND & $200-\mathrm{H}$ & 13.7 & 860 & 8.6 & 10.6 \\
\hline 200-I & 13.6 & 523 & 8.6 & 10.4 & ND & $200-\mathrm{I}$ & 13.7 & 860 & 8.5 & 10.4 \\
\hline 200-J & 13.6 & 555 & 8.5 & 9.2 & ND & $200-\mathrm{J}$ & 13.6 & 948 & 8.3 & 9.6 \\
\hline $200-\mathrm{K}$ & 13.5 & 550 & 8.4 & 10.3 & ND & $200-\mathrm{K}$ & 13.6 & 914 & 8.5 & 10.1 \\
\hline 200-L & 13.4 & 555 & 8.3 & 9.6 & ND & $200-\mathrm{L}$ & 13.5 & 954 & 8.3 & 9.6 \\
\hline 200-M & 13.5 & 513 & 8.5 & 10.1 & ND & 200-M & 13.5 & 899 & 8.5 & 10.2 \\
\hline $200-\mathrm{N}$ & 13.4 & 495 & 8.5 & 10.4 & ND & $200-\mathrm{N}$ & 13.5 & 871 & 8.5 & 10.4 \\
\hline
\end{tabular}




\section{Appendix 3F. Water-quality parameters for a 24-hour potassium chloride (KCI) exposure evaluating physiological impacts on brook trout at low baseline water conductivity (150 $\mathrm{SS} / \mathrm{cm})$.}

[ID, identifier; ${ }^{\circ} \mathrm{C}$, degrees Celsius; $\mathrm{mg} / \mathrm{L}$, milligrams per liter; $\mu \mathrm{S} / \mathrm{cm}$, microsiemens per centimeter; Note that the $\mathrm{T}=0$ conductivity reading is measured before the addition of $\mathrm{KCl}$ to the experimental tank whereas the ionized potassium $\left(\mathrm{K}^{+}\right)$measurement is taken following the potassium chloride (KCl) addition]

\begin{tabular}{|c|c|c|c|c|c|c|c|c|c|c|}
\hline \multicolumn{6}{|c|}{ Time $=0$ (Start) } & \multicolumn{5}{|c|}{ Time=24 hours (Terminus) } \\
\hline $\begin{array}{c}\text { Tank } \\
\text { ID }\end{array}$ & $\begin{array}{c}\text { Water } \\
\text { temperature, } \\
\text { in }{ }^{\circ} \mathrm{C}\end{array}$ & $\begin{array}{c}\text { Water } \\
\text { conductivity, } \\
\text { in } \mu S / c m\end{array}$ & $\begin{array}{c}\text { Water } \\
\text { pH }\end{array}$ & $\begin{array}{l}\text { Dissolved } \\
\text { oxygen, } \\
\text { in } \mathrm{mg} / \mathrm{L}\end{array}$ & $\begin{array}{c}\mathrm{K}^{+}, \\
\text {in } \mathrm{mg} / \mathrm{L}\end{array}$ & $\begin{array}{c}\text { Tank } \\
\text { ID }\end{array}$ & $\begin{array}{c}\text { Water } \\
\text { temperature, } \\
\text { in }{ }^{\circ} \mathrm{C}\end{array}$ & $\begin{array}{c}\text { Water } \\
\text { conductivity, } \\
\text { in } \mu S / \mathrm{cm}\end{array}$ & $\begin{array}{c}\text { Water } \\
\text { pH }\end{array}$ & $\begin{array}{c}\text { Dissolved } \\
\text { oxygen, } \\
\text { in mg/L }\end{array}$ \\
\hline $0-\mathrm{A}$ & 13.6 & 154 & 7.9 & 11.2 & 1 & $0-A$ & 13.5 & 164 & 8 & 11.6 \\
\hline $0-\mathrm{B}$ & 13.6 & 154 & 8 & 11 & 0 & $0-B$ & 13.6 & 165 & 8.1 & 11.6 \\
\hline $0-\mathrm{C}$ & 13.6 & 155 & 8 & 10.5 & 0 & $0-\mathrm{C}$ & 13.6 & 166 & 8 & 11.2 \\
\hline $0-\mathrm{D}$ & 13.6 & 154 & 7.9 & 10.5 & 0 & $0-\mathrm{D}$ & 13.6 & 165 & 8.1 & 11.3 \\
\hline $0-\mathrm{E}$ & 13.7 & 164 & 7.9 & 10.2 & 0 & $0-\mathrm{E}$ & 13.6 & 170 & 8 & 11.3 \\
\hline $0-\mathrm{F}$ & 13.7 & 156 & 7.8 & 10.3 & 0 & $0-\mathrm{F}$ & 13.7 & 165 & 8 & 11.2 \\
\hline $0-\mathrm{G}$ & 13.7 & 154 & 7.8 & 10.2 & 0 & $0-\mathrm{G}$ & 13.7 & 167 & 8 & 10.8 \\
\hline $0-\mathrm{H}$ & 13.5 & 160 & 8 & 10.7 & 0 & $0-\mathrm{H}$ & 13.6 & 166 & 8.1 & 11 \\
\hline $0-\mathrm{I}$ & 13.6 & 159 & 8.1 & 10.7 & 0 & 0 -I & 13.7 & 166 & 8.1 & 11.1 \\
\hline 0-J & 13.6 & 161 & 8 & 10.1 & 0 & $0-\mathrm{J}$ & 13.7 & 169 & 8 & 9.7 \\
\hline $0-\mathrm{K}$ & 13.6 & 159 & 8.1 & 9.9 & 0 & $0-\mathrm{K}$ & 13.7 & 170 & 8 & 10.6 \\
\hline $0-\mathrm{L}$ & 13.7 & 159 & 8 & 10.3 & 0 & $0-\mathrm{L}$ & 13.8 & 167 & 8.1 & 11.2 \\
\hline $0-\mathrm{M}$ & 13.7 & 158 & 8 & 10.6 & 0 & $0-\mathrm{M}$ & 13.8 & 165 & 8 & 11.1 \\
\hline $0-\mathrm{N}$ & 13.7 & 160 & 8 & 10.3 & 0 & $0-\mathrm{N}$ & 13.8 & 170 & 8 & 11.2 \\
\hline $200-A$ & 13.7 & 154 & 8.1 & 10.2 & 93 & $200-\mathrm{A}$ & 13.7 & 520 & 8.1 & 11.2 \\
\hline $200-B$ & 13.7 & 156 & 8 & 10.7 & 90 & $200-B$ & 13.7 & 550 & 8.1 & 11.2 \\
\hline $200-\mathrm{C}$ & 13.6 & 158 & 8.1 & 10.3 & 91 & $200-\mathrm{C}$ & 13.6 & 550 & 8 & 10.9 \\
\hline 200-D & 13.6 & 154 & 8.1 & 10.1 & 92 & $200-\mathrm{D}$ & 13.6 & 553 & 8 & 10.6 \\
\hline $200-E$ & 13.5 & 157 & 8.1 & 10.8 & 88 & $200-E$ & 13.5 & 491 & 8 & 10.6 \\
\hline $200-\mathrm{F}$ & 13.5 & 162 & 8.1 & 10.6 & 90 & $200-\mathrm{F}$ & 13.5 & 468 & 8.1 & 10.8 \\
\hline $200-\mathrm{G}$ & 13.5 & 162 & 8.1 & 10.5 & 91 & $200-\mathrm{G}$ & 13.4 & 478 & 8 & 10.2 \\
\hline $200-\mathrm{H}$ & 13.7 & 159 & 8 & 10.5 & 92 & $200-\mathrm{H}$ & 13.8 & 540 & 8 & 11.5 \\
\hline $200-\mathrm{I}$ & 13.7 & 159 & 8 & 10.6 & 94 & $200-\mathrm{I}$ & 13.7 & 539 & 8 & 10.6 \\
\hline $200-\mathrm{J}$ & 13.6 & 159 & 8 & 10.2 & 90 & $200-\mathrm{J}$ & 13.7 & 532 & 8 & 10.2 \\
\hline $200-K$ & 13.5 & 159 & 8 & 10.2 & 93 & $200-\mathrm{K}$ & 13.6 & 534 & 8 & 10.4 \\
\hline $200-\mathrm{L}$ & 13.6 & 160 & 8 & 9.7 & 90 & $200-\mathrm{L}$ & 13.7 & 547 & 8 & 10 \\
\hline 200-M & 13.5 & 160 & 8 & 10.4 & 98 & $200-\mathrm{M}$ & 13.6 & 562 & 8 & 10.6 \\
\hline $200-\mathrm{N}$ & 13.4 & 160 & 8 & 9.6 & 98 & $200-\mathrm{N}$ & 13.5 & 557 & 8.2 & 10.6 \\
\hline
\end{tabular}




\section{Appendix 3G. Water-quality parameters for a 10-day potassium chloride (KCI) exposure for the evaluation of physiological impacts on Chinook salmon.}

[ND, no data available; $\mathrm{K}^{+}$, ionized potassium; ${ }^{\circ} \mathrm{C}$, degrees Celsius; $\mathrm{mg} / \mathrm{L}$, milligrams per liter; ppm, parts per million]

\begin{tabular}{|c|c|c|c|c|c|c|c|}
\hline $\begin{array}{l}\text { Trial } \\
\text { day }\end{array}$ & $\begin{array}{c}\text { Water } \\
\text { temperature, } \\
\text { in }{ }^{\circ} \mathrm{C}\end{array}$ & $\begin{array}{c}\text { Water } \\
\text { conductivity, } \\
\text { in } \mu S / c m\end{array}$ & $\begin{array}{c}\text { Water } \\
\text { pH }\end{array}$ & $\begin{array}{c}\text { Estimated } \\
\text { dissolved } \\
\text { oxygen, } \\
\text { in } \mathrm{mg} / \mathrm{L}\end{array}$ & $\begin{array}{c}\text { Total } \\
\text { ammonia } \\
\text { nitrogen, } \\
\text { in } \mathrm{mg} / \mathrm{L}\end{array}$ & $\begin{array}{l}\text { Nitrate, } \\
\text { in } \mathrm{mg} / \mathrm{L}\end{array}$ & $\begin{array}{c}\mathrm{K}^{+}, \\
\text {in } \mathrm{mg} / \mathrm{L}\end{array}$ \\
\hline \multicolumn{8}{|c|}{0 milligrams per liter $\mathrm{KCl}$ (control) } \\
\hline 0 & 12.1 & 298 & 7.9 & 10.7 & 0 & ND & 1 \\
\hline 1 & 12.7 & 309 & 7.9 & 10.5 & 0 & ND & 1 \\
\hline 2 & ND & ND & ND & ND & ND & ND & ND \\
\hline 3 & 12.2 & 311 & 7.9 & 10.5 & 0 & ND & 1 \\
\hline 4 & 11.6 & 314 & 7.8 & 10.5 & 0 & ND & 1 \\
\hline 5 & ND & ND & ND & ND & ND & ND & ND \\
\hline 6 & 12.6 & 316 & 7.9 & 10.5 & 0 & ND & 1 \\
\hline 7 & 12.8 & 316 & 8 & 10.5 & ND & ND & 1 \\
\hline 8 & 12.2 & 319 & 8 & 10.5 & 0 & 4 & 1 \\
\hline 9 & 12.6 & 321 & 7.9 & 10.5 & ND & ND & 1 \\
\hline 10 & 11.9 & 322 & 8.1 & 10.5 & 0.05 & 5 & 1 \\
\hline \multicolumn{8}{|c|}{200 ppm KCl exposure } \\
\hline 0 & 11.8 & 287 & 7.8 & 10.5 & 0 & 2 & 1 \\
\hline 1 & 11.8 & 693 & 8 & 10.5 & 0 & 4 & 74 \\
\hline 2 & ND & ND & ND & ND & ND & ND & ND \\
\hline 3 & 11.7 & 698 & 7.8 & 10.5 & 0 & 4 & 70 \\
\hline 4 & 11.9 & 701 & 7.8 & 10.5 & ND & ND & ND \\
\hline 5 & 11.8 & 699 & 7.8 & 10.5 & 0 & 5 & 74 \\
\hline 6 & 11.9 & 706 & 7.8 & 10.5 & ND & ND & ND \\
\hline 7 & 12 & 707 & 7.9 & 10.5 & 0 & 6 & 71 \\
\hline 8 & ND & ND & ND & ND & ND & ND & ND \\
\hline 9 & 12 & 712 & 7.9 & 10.5 & 0 & 4 & 82 \\
\hline 10 & 11.7 & 716 & 7.8 & 10.5 & 1 & 4 & 82 \\
\hline
\end{tabular}




\section{Appendix 4. Behavioral and morphological changes observed among acute toxicity tests for Chinook salmon and brook trout.}

[These changes were observed among both species and in various potassium chloride $(\mathrm{KCl})$ test concentration groups and observation times, as noted. None of these changes were statistically significant (one-way analysis of variance [ANOVA]); $<<0.05 ; \mathrm{mg} / \mathrm{L}$, milligrams per liter]

\begin{tabular}{|c|c|c|c|c|}
\hline Species & Abnormality & $\begin{array}{c}\mathrm{KCl} \text { concentration } \\
\text { at effect, } \\
\text { in } \mathrm{mg} / \mathrm{L}\end{array}$ & $\begin{array}{l}\text { Duration } \\
\text { of exposure } \\
\text { at onset, } \\
\text { in days }\end{array}$ & $\begin{array}{c}\text { Total } \\
\text { number } \\
\text { of fish }\end{array}$ \\
\hline \multirow{2}{*}{ Brook trout } & Hyper-excitable swimming & 50,100 & 1 & 3 \\
\hline & Tail undulation at rest & 50 & 1 & 1 \\
\hline \multirow{7}{*}{ Chinook salmon } & Mildly elevated respiratory rate & $25,50,400$ & $1+$ & 6 \\
\hline & Hyper-excitable swimming & $0,25,50,100,200,800$ & $1+$ & 24 \\
\hline & Mildly lethargic swimming & 800 & 4 & 1 \\
\hline & Deformed/damaged opercle & $100,200,400$ & $1+$ & 9 \\
\hline & Coughing & 25 & 1 & 1 \\
\hline & Hypopigmentation & 200 & 4 & 1 \\
\hline & Hyperpigmentation & 400 & 4 & 1 \\
\hline
\end{tabular}




\section{Appendix 5. Histological changes noted among brook trout and Chinook salmon in the 96-hour acute toxicity testing.}

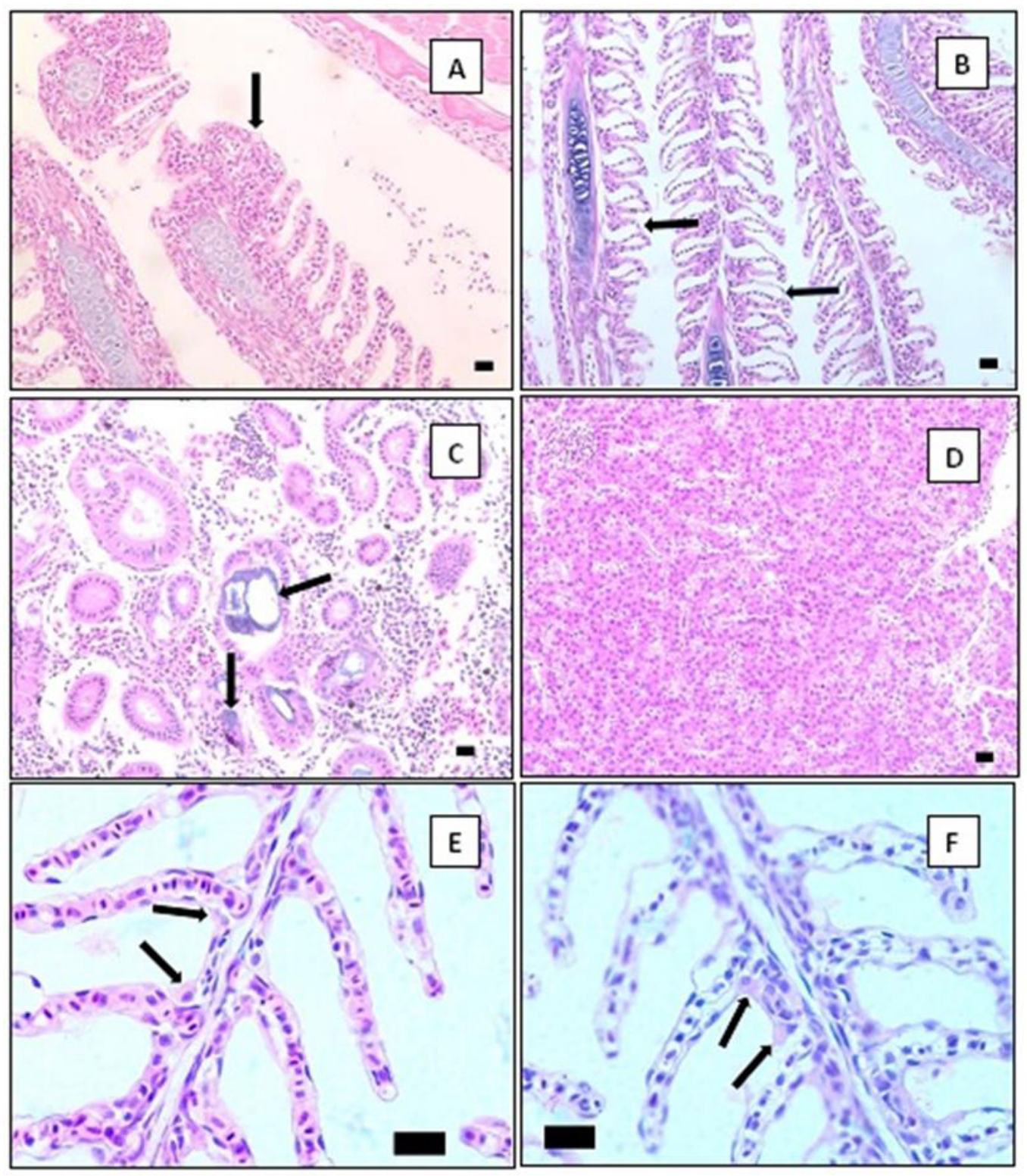

Figure 5-1. None of the changes were significantly different in frequency of occurrence among the test groups and all were noted incidentally with no clinical indication of disease among the fish: $A$, Epithelial lifting of gill lamellae (Chinook salmon); $B$, Gill epithelial hyperplasia along distal lamellae (brook trout); $C$, Mineral deposition in tubule lumen with the excretory kidney; $D$, Hepatocellular vacuolation; $E$, Interlamellar chloride cells along the gill epithelium in a brook trout; $F$, Interlamellar chloride cells along the gill epithelium in a Chinook salmon. Black arrows indicate the histological change/finding and black scale bars within each photograph represent 20 microns length. 


\section{Appendix 6. Log probit analysis calculation of the potassium chloride lethal concentration $\left(\mathrm{KCI} \mathrm{LC}_{50}\right.$ ) concentrations for daphniid toxicity trials.}

[Probit analyses are displayed as graphs and tabular data for the $\mathrm{LC}_{50}$ calculations at 2 hours, 4 hours, 24 hours, and 48 hours]
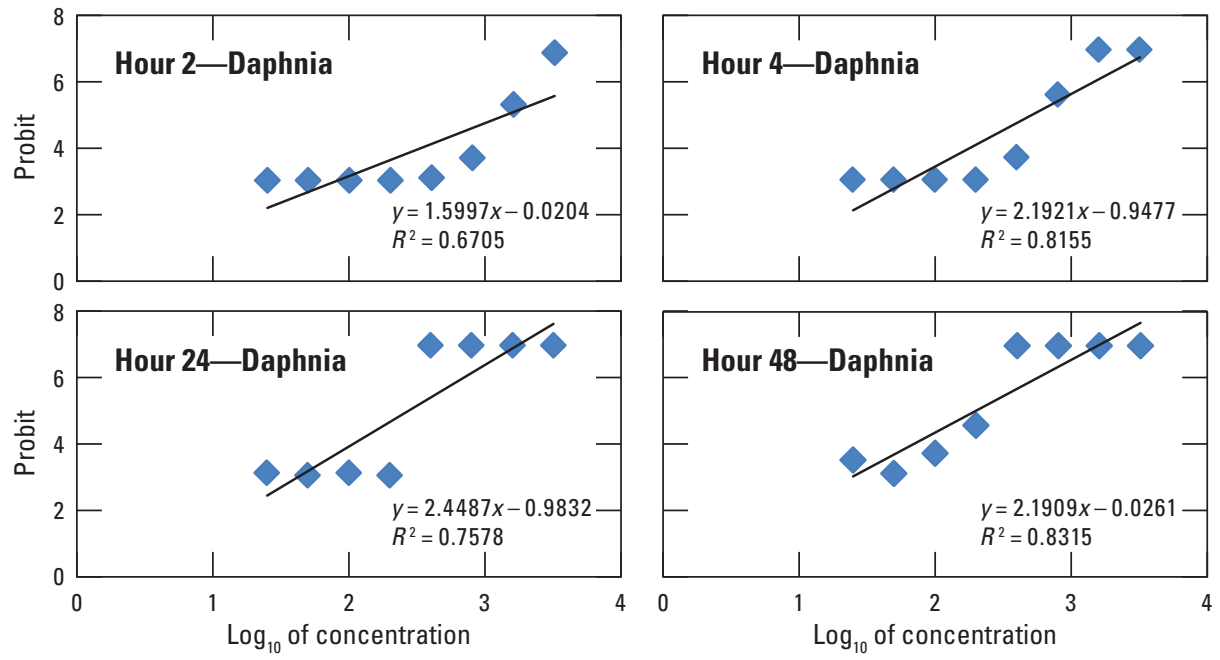

\begin{tabular}{|c|c|c|c|c|c|c|}
\hline Concentration & $\begin{array}{c}\log _{10} \text { of } \\
\text { concentration }\end{array}$ & Percent dead & $\begin{array}{c}\text { Corrected } \\
\text { percent }\end{array}$ & Probit & $\begin{array}{c}\text { Calculated } \mathbf{L C}_{50^{\prime}} \\
\text { in milligrams per liter }\end{array}$ & $\begin{array}{c}\log _{10} \text { of concentration } \\
\text { at probit=5 }\end{array}$ \\
\hline \multicolumn{7}{|c|}{ Hour 2} \\
\hline 25 & 1.397940009 & 0 & 2.5 & 3.04 & \multirow{8}{*}{$1,375.111772$} & \multirow{8}{*}{3.138338438} \\
\hline 50 & 1.698970004 & 0 & 2.5 & 3.04 & & \\
\hline 100 & 2 & 0 & 2.5 & 3.04 & & \\
\hline 200 & 2.301029996 & 0 & 2.5 & 3.04 & & \\
\hline 400 & 2.602059991 & 3 & 3 & 3.12 & & \\
\hline 800 & 2.903089987 & 10 & 10 & 3.72 & & \\
\hline 1,600 & 3.204119983 & 63 & 63 & 5.33 & & \\
\hline 3,200 & 3.505149978 & 97 & 97 & 6.88 & & \\
\hline \multicolumn{7}{|c|}{ Hour 4} \\
\hline 25 & 1.397940009 & 0 & 2.5 & 3.04 & \multirow{8}{*}{516.7054103} & \multirow{8}{*}{2.713243009} \\
\hline 50 & 1.698970004 & 0 & 2.5 & 3.04 & & \\
\hline 100 & 2 & 0 & 2.5 & 3.04 & & \\
\hline 200 & 2.301029996 & 0 & 2.5 & 3.04 & & \\
\hline 400 & 2.602059991 & 10 & 10 & 3.72 & & \\
\hline 800 & 2.903089987 & 73 & 73 & 5.61 & & \\
\hline 1,600 & 3.204119983 & 100 & 97.5 & 6.96 & & \\
\hline 3,200 & 3.505149978 & 100 & 97.5 & 6.96 & & \\
\hline \multicolumn{7}{|c|}{ Hour 24} \\
\hline 25 & 1.397940009 & 3 & 3 & 3.12 & \multirow{8}{*}{277.5996773} & \multirow{8}{*}{2.443418957} \\
\hline 50 & 1.698970004 & 0 & 2.5 & 3.04 & & \\
\hline 100 & 2 & 3 & 3 & 3.12 & & \\
\hline 200 & 2.301029996 & 0 & 2.5 & 3.04 & & \\
\hline 400 & 2.602059991 & 100 & 97.5 & 6.96 & & \\
\hline 800 & 2.903089987 & 100 & 97.5 & 6.96 & & \\
\hline 1,600 & 3.204119983 & 100 & 97.5 & 6.96 & & \\
\hline 3,200 & 3.505149978 & 100 & 97.5 & 6.96 & & \\
\hline \multicolumn{7}{|c|}{ Hour 48} \\
\hline 25 & 1.397940009 & 7 & 7 & 3.52 & \multirow{8}{*}{196.8249084} & \multirow{8}{*}{2.294080058} \\
\hline 50 & 1.698970004 & 3 & 3 & 3.12 & & \\
\hline 100 & 2 & 10 & 10 & 3.72 & & \\
\hline 200 & 2.301029996 & 33 & 33 & 4.56 & & \\
\hline 400 & 2.602059991 & 100 & 97.5 & 6.96 & & \\
\hline 800 & 2.903089987 & 100 & 97.5 & 6.96 & & \\
\hline 1,600 & 3.204119983 & 100 & 97.5 & 6.96 & & \\
\hline 3,200 & 3.505149978 & 100 & 97.5 & 6.96 & & \\
\hline
\end{tabular}



For additional information, contact:

Director, Leetown Science Center U.S. Geological Survey

11649 Leetown Road

Kearneysville, WV 25430

or visit our website at: https://www.lsc.usgs.gov

Publishing support provided by the West Trenton Publishing Service Center 

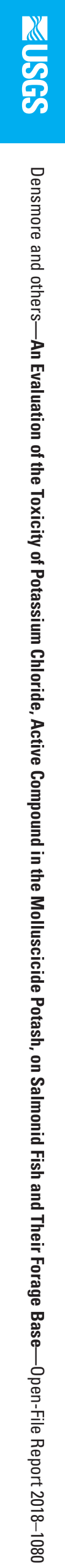